\title{
Glass Filters for Checking Performance of Spectrophotom- eter-Integrator Systems of Color Measurement
}

\author{
Harry J. Keegan, John C. Schleter, and Deane B. Judd
}

(January 16, 1962)

\begin{abstract}
A set of five specially selected colored-glass filters to identify variables of malfunction of photoelectric recording spectrophotometers equipped with tristimulus integrators have been standardized on a number of spectrophotometers corrected for all known errors (wavelength, zero, 100 percent, slit-width, inertia, back-reflectance, and stray-energy). To these standardized spectrophotometric data definite amounts of these errors were deliberately introduced and converted to tristimulus values and chromaticity coordinates of the International Commission of Illumination system of colorimetry for Sources $A, B$, and $C$. Similar reductions show the effects of slit widths of $1,5,10$, and 15 millimicrons $(\mathrm{m} \mu)$ on computed results both by the selected-ordinate method of 10,30 , and 100 ordinates, and by the weighted-ordinate methods of 1-, 5-, 10-, and $15-\mathrm{m} \mu$ intervals. Duplicate sets of these glasses have been evaluated by visual comparison with this set of master standards, and are available as part of the Standard Materials Program of the National Bureau of Standards. By comparing the certified values of luminous transmittance and chromaticity coordinates for a set of these glasses with the values obtained on a particular integrator-spectrophotometer combination, the type and extent of instrumental errors may be evaluated.
\end{abstract}

\section{Introduction}

In 1956, Dr. Nathaniel H. Pulling, Instrument Department, General Electric Co., West Lynn, Mass., proposed that the National Bureau of Standards develop a set of four or five non-light-scattering glasses to serve as standards of tristimulus values to check performance of colorimeters, particularly the automatic spectrophotometer equipped with integrator. At that time it was believed that such a set of filters might consist of a selenium red, a selenium vellow, a dense cobalt, and a nearly nonselective glass of 15 to 20 percent transmittance. Although the certified tristimulus values would be intended to be those corresponding to an extrapolation to "zero slit width" (the band pass of a spectrophotometer so small that further reduction will not affect the photometric value), the glasses might serve also to check the adjustment of an integrator attached to a spectrophotometer with $10-\mathrm{m} \mu$ slits by giving in the paper describing the development of the standards the tristimulus values of the master standards not only for zero slit width, but also those found for $4-\mathrm{m} \mu$ and $10-\mathrm{m} \mu$ slits.

Because there were no accepted means in industry for checking the performance of spectrophotometerintegrator systems, two meetings were held at the National Bureau of Standards with representatives of manufacturers of spectrophotometers, glass manufacturers, and industrial users of spectrophotometers with tristimulus integrators. At the meeting held on September 11, 1957, fifteen representatives of industry attended and confirmed the need for glass standards to check spectrophotometer-integrator systems. A second meeting on May 14, 1958 reviewed a selection of five types of filters and approved of their standardization. Typical spectrophotometric curves of the five glasses selected for study are shown in figure 1.

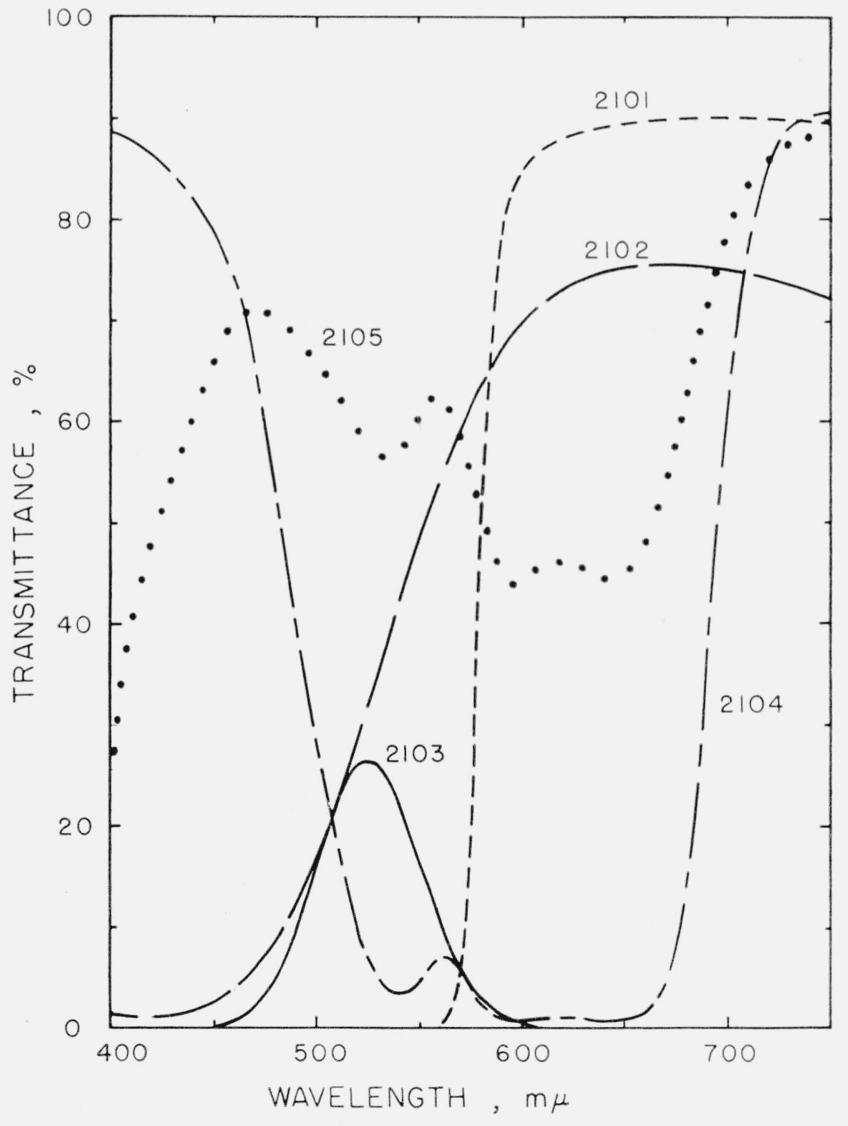

Figure 1. Spectral transmittance of the five NBS standard materials for checking spectrophotometer-integrator systems. 2101, Selenium Orange Red; 2102, Signal Yellow; 2103, Sextant Green; 2104, Cobalt Blue; 2105, Selective Neutral. 
Materials. Two hundred $2 \times 2$-in. polished squares of each of five types of glass, each group of 200 squares being from the same melt, were purchased from Corning Glass Works. Our designations for the five types of glass, the Corning designation, and thickness are as follows:

2101, Selenium orange red, Corning 3480, $2.6 \mathrm{~mm}$. 2102, Signal yellow, Corning 3307, $2.6 \mathrm{~mm}$.

2103, Sextant green, Corning 4010, $4.4 \mathrm{~mm}$.

2104, Cobalt blue, Corning 5551, $2.6 \mathrm{~mm}$.

2105, Selective neutral, special glass developed by

Corning for this project, Corning 5045, $2.9 \mathrm{~mm}$.

Three sets of these five glasses were arbitrarily selected and designated Master No. 1, Master No. 2, and Master No. 3. Later two sets of limit glasses for each of the five glasses were selected as described in 2.3 below.

\section{Method}

\subsection{Spectrophotometry of Master Standards}

Measurements of spectral transmittance were made on each of the three master standards and the two limit standards on the Cary Model 14 and the General Electric $[1,2]^{1}$ recording spectrophotometers, with check measurements on Master No. 3 set on the Beckman DU indicating spectrophotometer and on the König-Martens visual spectrophotometer.

The methods of using three of these spectrophotometers have been previously described $[3,4,5]$. The methods of using the Cary spectrophotometer are described in detail in section 2.1.a.

Additional corrections made on the GE spectrophotometer data are explained in section 2.1.b.

Details of the measurements on the Beckman DU and the $\mathrm{K}-\mathrm{M}$ spectrophotometers are explained in section 2.1.c.

\section{a. Cary Recording Spectrophotometer}

Measurements. Spectral-transmittance measurements were made on each of fifteen glass filters comprising three sets of five master filters designated Master No. 1, No. 2, and No. 3, on a Cary Model 14M (Serial No. 173) recording spectrophotometer at the National Bureau of Standards for the following conditions:

(1) Temperature control. Measurements were made under conditions of controlled temperature on both the laboratory $\left(25^{\circ} \mathrm{C}\right)$ and in the sample compartment of the spectrophotometer $\left(22^{\circ} \mathrm{C}\right)$. The same temperature-controlled water which cooled the sample compartment was circulated around the monochromator to assist in maintaining the wavelength stability of the instrument.

(2) Scanning rate and chart speed. The monochromator scan was driven at a speed of $0.25 \mathrm{~m} \mu / \mathrm{sec}$ and the chart speed of the recorder was $5 \mathrm{in} . / \mathrm{min}$. This combination of scanning rate and chart speed resulted in recordings having a wavelength scale of $1 \mathrm{~m} \mu /$ chart division. The slow scanning rate was chosen to reduce the inertia effect in the recording mechanism during the recording of steep portions of the transmittance curves.

\footnotetext{
1 Figures in brackets indicate the literature references at the end of this paper.
}

(3) Wavelength calibration. The wavelength scale of the spectrophotometer, as it is recorded on the chart at the above scan rate and chart speed, was calibrated by means of the emission lines of a mercury source. It was found that by applying a correction of $+0.2 \mathrm{~m} \mu$ over the range 380 to $770 \mathrm{~m} \mu$ in reading the spectral-transmittance data of the filters from the recordings the wavelength-scale errors were satisfactorily taken into account.

(4) Slide wire. The recorder of the spectrophotometer was equipped with a density $(-\log T)$ slide wire. The recorder covers the density range of 0 to 2 using two pens, one recording the density range 0 to 1 $(100 \% \mathrm{~T}$ to $10 \% \mathrm{~T})$; the other, the range 1 to $2(10 \% \mathrm{~T}$ to $1 \% T$ ). The transfer from the first pen to the second pen is automatic. For some of the filters, such as the 2101 orange-red, the density of the filter exceeds density 2 . In these cases, photoetched nickel screens were introduced into the comparison beam of the spectrophotometer to extend the range. Two such screens were used, each having a density slightly greater than density 1 , which thus allowed the measurements to be made to approximately density 4. Measurements were made of the spectral transmittance of the screens over the entire wavelength range.

(5) Zero curve. The zero-density curve $(100 \% T)$ on the Cary can be adjusted by means of potentiometers so as to read approximately zero at all wavelengths regardless of the source-detector combination used. Since it is not possible to make the adjustment agree perfectly at all wavelengths, a zero-density curve was run for the entire wavelength range being used, before and after a series of measurements on the filters.

(6) Slit width. The physical slit width of the monochromator during the measurement of the filters was $0.1 \mathrm{~mm}$ or less for densities less than 2 . From the dispersion curve of the monochromator supplied by the manufacturer, it was determined that the band pass of the monochromator for these slit widths varied from approximately 0.3 to $0.4 \mathrm{~m} \mu$ for the wavelength range covered. As the screens are introduced into the comparison beam, the slit width of the monochromator increases. It is estimated that the band pass was approximately $1 \mathrm{~m} \mu$ or less for the density range 0 to 3 .

(7) Source-detector. Two source-detector combinations were used for these measurements of spectral transmittance. For the wavelength range 360 to $600 \mathrm{~m} \mu$, the "visible" tungsten source and 1P28 multiplier phototube were used. The "infrared" tungsten source and lead sulfide cell were used for the wavelength range 550 to $790 \mathrm{~m} \mu$.

Data reduction. The recordings of spectral transmittance of the filters and the screens were read at each $1-\mathrm{m} \mu$ interval from 360 to $790 \mathrm{~m} \mu$. The wavelength correction of $+0.2 \mathrm{~m} \mu$ was applied at each wavelength read. The zero-density curves run before and after the particular measurement of a filter or screen were read and averaged, and subtracted from the reading of the filter or screen. Where screens were used to increase the photometric range of the spectrophotometer, the density of the 
screen at that wavelength was added to that recorded for the filter. In the wavelength region 550 to 600 $\mathrm{m} \mu$, where data were taken both with the multiplier phototube and with the lead sulfide cell, an average of the two sets of data was tentatively used. After the corrections for the zero-density curve and the screens had been made, the data were coded for introduction into the IBM 704 high-speed digital computer for conversion from a logarithmic to a linear scale.

It was found that the data taken with the lead sulfide cell differed slightly but systematically from the data taken with the multiplier phototube in the wavelength region 550 to $600 \mathrm{~m} \mu$ where the two sets of data overlapped. Although the average data in this wavelength region were used for some of the preliminary computations, corrected data from the lead sulfide cell were used for the finally adopted data. The correction to the lead sulfide cell data was made by taking the density difference between the multiplier phototube and the lead sulfide cell data at $600 \mathrm{~m} \mu$ and applying this difference to the density data from the lead sulfide cell for the wavelength range 610 to $770 \mathrm{~m} \mu$. The multiplier-phototube data were used for the wavelength range 380 to $600 \mathrm{~m} \mu$. The corrected data for the lead sulfide cell were converted from a logarithmic to a linear scale and combined with the multiplier phototube data to form the adopted data for the Cary.

\section{b. General Electric Spectrophotometer}

Comparison of the spectral transmittances of the five glasses of master set No. 3 obtained on the GE-II ${ }^{2}$ recording spectrophotometer, after routine zero, 100 percent, and wavelength-scale corrections had been applied, with the average spectral transmittances obtained for the same glasses on the Cary-14, the Beckman DU, and the König-Martens spectrophotometers showed small but regular discrepancies. Examination of these discrepancies suggested that they are ascribable to the combined effects of error sources already identified, but hitherto often regarded individually as yielding errors in general either nearly or completely negligible. These sources of error are of three kinds and will be hereafter identified as slit-width errors, inertia errors, and back-reflectance errors.

Slit-width errors. The slit function of the GE-II spectrophotometer is approximated closely by an isosceles triangle whose apex is at the wavelength, $\lambda$, and whose base extends from $\lambda-10 \mathrm{~m} \mu$ to $\lambda+10$ $\mathrm{m} \mu$, giving a width at half height equal to $10 \mathrm{~m} \mu[6]$. By slit-width cams this width is maintained nearly constant independent of wavelength [7]. A simple formula for correction of slit-width errors may be derived by assuming the correction to be proportional to the second derivative of the spectraltransmittance $\left(T_{\lambda}\right)$ function of the filter, and by approximating this second derivative by the difference between twice the reading, $R_{\lambda}^{\prime}$, at wavelength $\lambda$ and the sum of the readings $R_{\lambda-10}^{\prime}$ and $R_{\lambda+10}^{\prime}$, pre732986 . ceding and following this wavelength by $10 \mathrm{~m} \mu$. The formula:

$$
\begin{aligned}
T_{\lambda} & =R_{\lambda}^{\prime}+\left(2 R_{\lambda}^{\prime}-R_{\lambda-10}^{\prime}-R_{\lambda+10}^{\prime}\right) / 10 \\
& =1.2 R_{\lambda}^{\prime}-0.1 R_{\lambda-10}^{\prime}-0.1 R_{\lambda+10}^{\prime}
\end{aligned}
$$

is equivalent to the first terms of the expansion form quoted by Gibson [6] from Forsythe [7] with $K$ taken as 10 instead of 12 . The terms, $R_{\lambda}^{\prime}, R_{\lambda-10}^{\prime}$, and $R_{\lambda+10}^{\prime}$, refer to values obtained from the GE-II spectrophotometer with all corrections applied except that for slit-width error.

Since the 5 glasses of master set No. 3 had been measured at each millimicron throughout the visible spectrum by means of the Cary- 14 spectrophotometer with slit widths not exceeding $1 \mathrm{~m} \mu$ for transmittances greater than 1 percent, it was possible to compute the values of spectral transmittance that would have been read by an instrument having slit widths of any value greater than $1 \mathrm{~m} \mu$. Such computations were made for a triangular slit function with a width of $10 \mathrm{~m} \mu$ at half height, and the differences between the resulting values and those for the narrow slits of the Cary spectrophotometer were applied to the GE-II readings as slit-width corrections. It was noted, however (see columns 3 and 4 of table 1), that approximately the same corrections were obtainable from formula (1); so this formula is a convenient short way to state the sizes of the slit-width corrections applied, and is also a satisfactory simple statement of slit-width corrections to be applied to other specimens measured on the GE-II spectrophotometer.

Inertia errors. The recording mechanism of the automatic GE-II spectrophotometer is controlled by positive and negative impulses operating on the pen assembly (driving motor, gears, and pen holder) which has appreciable interia and friction. This mechanism gives a dynamic evaluation of the transmittance at wavelength $\lambda$; that is, the transmittanceindicating position of the pen at the time, $t$, when the specimen is being illuminated by light of wavelength, $\lambda$, is based on signals received at a time, $t-c$, somewhat before wavelength, $\lambda$, is reached. The pen position at time, $t$, is thus found by extrapolation over the time interval, $c$. This extrapolation process depends on the strength and frequency of the impulses relative to the inertia and friction of the pen assembly. On a rising curve the pen assembly may coast past the correct value because of inertia, or it may lag behind because of friction. The discrepancy between the true value of the spectral transmittance and the value recorded by extrapolation may be called the inertia error. Let us assume that if $R_{o}(t)$ is the correct reading at time, $t$, the actual reading $R(t)$, will, because of inertia error, be a function not only of $R_{0}(t)$, but also of the velocity of the pen assembly at time, $t-c$, just previous to time, $t$, of the following simple form:

$$
R(t)=R_{0}(t)+k(d R / d t)_{t-c}
$$

where $c$ and $k$ are constants to be evaluated from a consideration of $R-R_{o}$ for known specimens. 
TABLE 1. Spectral transmittances of master set No. 3 orange-red glass filter 2101

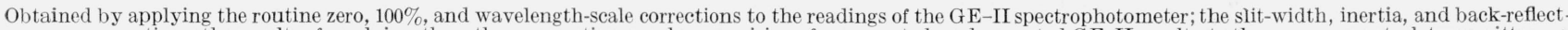

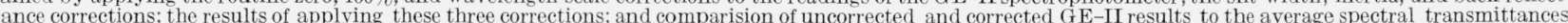
of the same glass filter obtained by three other spectrophotometers (Cary-14, Beckman DU, König-Martens)

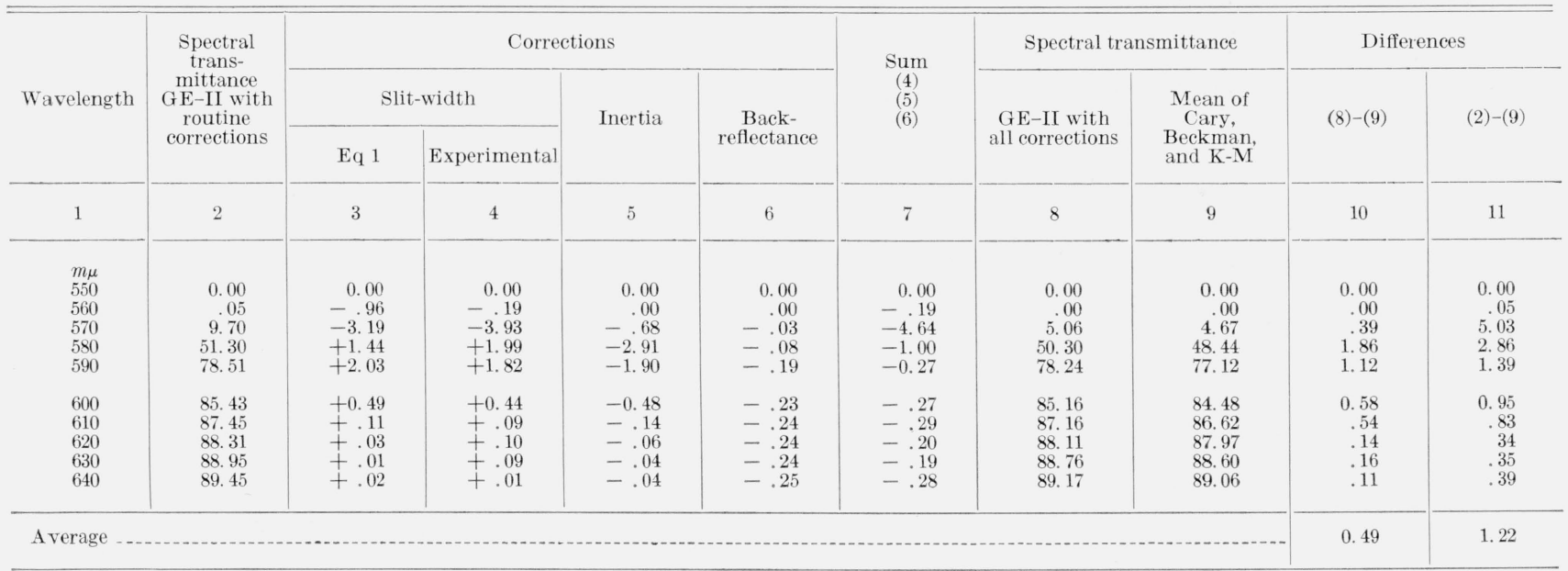

The correction, $R_{0}-R$, to be added to $R$ to obtain the true value, $R_{0}$, may be estimated with some reliability by taking $-k\left(R_{\lambda}-R_{\lambda-2 c}\right)$ from the recorded curve. This shift from the time scale to the wavelength scale is justified because the instrument scans the spectrum in the direction of increasing wavelength with a constant speed. The assumption that the inertia of the pen assembly has a significant regular influence on the reading $R(\vec{t})$ does not involve a decision between a tendency of the assembly to lag behind the correct reading or jump ahead of it. This decision has to be made in the course of evaluating the constant, $k$, from a consideration of $R-R_{0}$ for known specimens. If $k$ is found to be greater than zero the inertia correction refers to a correction for lag; if less than zero, to a correction for lead.

The empirical evaluation was based partly on data taken several years ago by Keegan [8] (1956) and partly on the present data for the five glasses of master set No. 3. The best fit to the 1956 data was found by setting $c=5 \mathrm{~m} \mu$, and $k$ either at -0.05 or -0.07 . The best fit to the present data was found for $c=5 \mathrm{~m} \mu, k=-0.07$. Note that both sets of data indicate $k$ less than zero. The inertia correction for the GE-II spectrophotometer is thus a lead correction. If $R_{\lambda}$ and $R_{\lambda-10}$ are the uncorrected readings of the spectrophotometric curve plotted by the instrument, the formula for speciral transmittance, $T_{\lambda}$, with this evaluation of constants becomes

$$
\begin{aligned}
T_{\lambda} & =R_{\lambda}-0.07\left(R_{\lambda}-R_{\lambda-10}\right) \\
& =0.93 R_{\lambda}+0.07 R_{\lambda-10}
\end{aligned}
$$

on the assumption that all other corrections are negligible. Optimally this inertia correction should be made first, followed by the zero correction, the 100 percent correction, the wavelength-scale correction, the slit-width correction, and finally the backreflectance correction, but in practice these corrections are sufficiently small that no significant addi- tional error is introduced by changes in the order of applying them.

Back-reflectance errors. Through the specimen compartment of the GE-II spectrophotometer, two divergent beams pass from the decentered lenses to the entrance ports of the integrating sphere [2]. The axis of each beam makes an angle of about $6^{\circ}$ with the optical axis of the instrument, one to the right, the other to the left. The specimen filter whose spectral transmittance is to be measured is inserted in one of these beams (the specimen beam) so that the axis of the beam is perpendicular to the faces of the filter. All of the flux reflected from the front face of the filter and a fraction of the flux reflected from the back face contributes to a reflected beam directed back toward the decentered lens. Since this reflected beam is also diverging, part of it may, and as a matter of fact does, reach the decentered lens transmitting the reference beam, as was pointed out by Middleton [9], and enters the sphere through the entrance port of the reference beam. This added flux, some of which has never passed through the specimen, contributes to the illuminance of the sphere during the specimen phase of the cycle and causes a spuriously high indication of the spectral transmittance of the specimen. This error is what is meant by back-reflectance error. It could be eliminated by insertion of an inconvenient vertical partition between the specimen compartment and the decentered lenses; but since the error for nonmetallized glass filters is of the order of one or two tenths of one percent of the full scale, it has heretofore been considered negligible.

By obtaining the reading of the spectral transmittance of a clear plate first inserted perpendicular to the specimen beam, and second tilted until no part of the reflected beam crosses over to the other side of the instrument, it was found that the maximum error from this source for a glass of refractive index equal to 1.5 is 0.0026 . By taking into account the fact that as the transmittance decreases from 0.923 
to zero, the reflectance of the specimen filter declines from 0.079 to 0.040 , and that the photometer scale is adjusted to be correct at 0.10 , the following expression for the reflection correction accurate to 0.0001 was derived:

Back-reflectance correction $=-0.0031 R_{\lambda}{ }^{2}$,

where $R_{\lambda}$ is defined in formula (2).

This correction was applied to all of the data on the glasses of master set No. 3 obtained on the GE-II spectrophotometer.

To indicate the degree to which the three often neglected corrections (slit-width, inertia, backreflectance) succeeded in accounting for the regular deviations of the results by the GE-II spectrophotometer from the mean of those by three other spectrophotometers (Cary-14, Beckman DU, KönigMartens), table I has been prepared for the selenium orange-red glass (2101) of master set No. 3 for the wavelength range 550 to $640 \mathrm{~m} \mu$. It may be seen from columns 10 and 11 that, by applying these three, often neglected corrections, both the maximum difference and the average difference between the GE-II results and the mean of results by three other spectrophotometers have been reduced by more than a factor of 2 . The $\mathrm{GE}-\mathrm{II}$ reads higher on glass filter 2101 than the other spectrophotometers, even after these negative corrections have been applied. The causes of these residual deviations (column 10) are not known. The GE-II with all known corrections applied agrees notably better with the other spectrophotometers in its measurement of the other four glasses of master set No. 3.

\section{c. Beckman DU and König-Martens Spectrophotometers}

Check measurements of spectral transmittance of the five master standards of set No. 3 were made at certain wavelengths on the Beckman DU and the $\mathrm{K}-\mathrm{M}$ spectrophotometers as follows:

On Beckman DU spectrophotometer

(1) Glass 2101 on "absolute basis" 560 to $750 \mathrm{m \mu}$ at every $10 \mathrm{~m} \mu$.

(2) Glass 2102 relative to spectrophotometric standard Corning HT yellow $[5,6]$ at wavelengths at which the standard is specified.

(3) Glass 2103 on "absolute basis," 450 to $610 \mathrm{m \mu}$ at every $10 \mathrm{~m} \mu$.

(4) Glass 2104 relative to spectrophotometric standard cobalt blue $[5,6]$ at wavelengths at which standard is specified.

(5) Glass 2105 on "absolute basis," 400 to $750 \mathrm{m \mu}$ at every $10 \mathrm{~m} \mu$.

On $\mathrm{K}-\mathrm{M}$ spectrophotometer

(1) Glass 2101 at the wavelengths $560,578(\mathrm{Hg}$ line), and $620 \mathrm{~m} \mu$.

(2) Glass 2102 at wavelengths 436 ( $\mathrm{Hg}$ line) and $620 \mathrm{~m} \mu$.

(3) Glass 2103 at wavelengths 460, 520, 600, 610, and $620 \mathrm{~m} \mu$.

(4) Glass 2104 at wavelengths 595 and $645 \mathrm{~m} \mu$.

(5) Glass 2105 at wavelengths $470,530,595,620$, and $640 \mathrm{~m} \mu$.
Stray-energy filters used for the Beckman DU spectrophotometer were Corning 9863 for 320 to $400 \mathrm{~m} \mu$, Corning 2424 with blue-sensitive cell from 600 to $660 \mathrm{~m} \mu$ and Corning 3965 with red-sensitive cell. Similarly appropriate stray-energy filters were used on the K-M.

\subsection{Evaluation of Errors}

In order to evaluate errors in the computation of tristimulus values and chromaticity coordinates due to (1) neglect of slit-width corrections, (2) the use of summation-intervals of various sizes in the weighted-ordinate method, and (3) the use of various numbers of ordinates in the selected-ordinate method, a computer program was prepared for the IBM 704 high-speed digital computer.

This program converts data of spectral transmittance into colorimetric terms for slit-widths of 1 (near-zero), 5,10 , and $15 \mathrm{~m} \mu$ by (a) the weightedordinate method for $1-, 5-, 10-$, and $15-\mathrm{m} \mu$ summation intervals, and (b) the selected-ordinate method for 10,30 , and 100 ordinates. The conversions can be made for any Planckian source from approximately $1,000{ }^{\circ} \mathrm{K}$ to $10,000{ }^{\circ} \mathrm{K}$ including CIE standard source, $A$, and for CIE sources $B$, and $C$. Published values of the tristimulus functions $(\bar{x}, \bar{y}, \bar{z})$ for each $1-\mathrm{m} \mu$ interval from 380 to $770 \mathrm{~m} \mu$ and the wavelength of the selected ordinates for 10,30 , and 100 ordinates are used in the program [10].

The input data for this program are values of spectral transmittance for each $1-\mathrm{m} \mu$ interval from 360 to $790 \mathrm{~m} \mu$ measured on an instrument with a band pass so small that further reduction will not affect the photometric value. The data must be corrected for wavelength, zero curve, and 100 percent curve instrumental errors before introduction into the program.

\section{a. Neglect of Slit-Width Corrections}

The effect of the change in slit width on the $1-\mathrm{m} \mu$ (near zero) slit-width, spectral-transmittance, input data were computed by using a triangular slit-width weighting function of the type:

$$
T_{\lambda}=\left(\sum_{i=0}^{n}\left[(n-i) T_{\lambda-i}+(n-i) T_{\lambda+i}\right]-n T_{\lambda}\right) / n^{2},
$$

where $T_{\lambda}$ is the spectral transmittance at wavelength $\lambda, n$ is the nominal slit width, and $i$ is a wavelength difference less than or equal to $n$. The spectraltransmittance data were computed for each $1-m \mu$ interval from 380 to $770 \mathrm{~m} \mu$ for $n=5,10$, and 15 . The colorimetric coordinates $X, Y, Z, x, y$ were computed for the spectral transmittance data for 1-, 5-, 10-, and $15-\mathrm{m} \mu$ slit widths using the weightedordinate method for a $1-\mathrm{m} \mu$ summation interval. The colorimetric coordinates indicate the effect to be expected when the glass filters are measured on spectrophotometers having slit widths larger than $1 \mathrm{~m} \mu$. 
b. Use of Summation Intervals of Various Sizes in the WeightedOrdinate Method

From the spectral-transmittance input data for $1-\mathrm{m} \mu$ slit width and the spectral-transmittance data computed from them for 5-, 10-, and $15-\mathrm{m} \mu$ slit widths, the colorimetric coordinates $X, Y, Z, x, y$ were computed by the weighted-ordinate method from every 5th, 10th, and 15 th value of spectral transmittance, tristimulus function, and spectral irradiance of the source. The resulting colorimetric coordinates indicated the change which would be expected by using summation intervals of 5,10 , and $15 \mathrm{~m} \mu$ with the weighted-ordinate method.

\section{c. Use of Various Numbers of Ordinates in the Selected-Ordinate Method}

The colorimetric coordinates were then computed for the spectral transmittance data for the four slit widths by means of the selected-ordinate method for 10,30 , and 100 ordinates. The correct values of spectral transmittance at the wavelength indicated by the selected-ordinates used were computed by third-difference osculatory interpolation [11]. The resulting colorimetric coordinates indicated the change which could be expected by using the selectedordinate method for 10,30 , and 100 ordinates.

\subsection{Colorimetry of Duplicates}

From the 200 squares of each type of glass, 100 were chosen by visual inspection for issuance as duplicate standards. The crit eria were freedom from seeds, bubbles, striae, scratches, chips, and other visually detectable defects.

Although the 100 glass squares of each type of glass so chosen were taken from the same melt, visual inspection by diffused light from daylight fluorescent lamps revealed small color differences among them. By means of these differences it was possible to arrange the 100 glasses in an essentially one-dimensional sequence, and from this sequence the terminal glasses (called limit filters) were chosen to indicate the color range of the group as follows:

Orange red __ weak limit (WL) and strong limit (SL). Yellow _._. _ _ weak limit (WL) and strong limit (SL). Green . . . . _yellow limit (YL) and blue limit (BL). Blue _._. light limit (LL) and dark limit (DL). Neutral _. _. _yellow limit (YL) and blue limit (BL).

The limit filters so selected were measured on the General Electric, and Cary spectrophotometers, and on the Barnes, Gardner, Hunter, Colormaster, and Judd CDC (chromaticity difference colorimeter) colorimeters. An analysis of the data so obtained showed that smaller uncertainties would be obtained if no photoelectric colorimeter was used for the duplicate standards. Accordingly, measurements were made on the 100 glasses in each of the red, yellow, and blue sets by means of the CDC visual colorimeter.

The chromaticity-difference $(\Delta x, \Delta y)$ data so obtained showed that the color differences among the yellow and blue glasses were ascribable to small variations in the thicknesses of the glasses. The measured thicknesses of the glasses were used to find adopted values of $X, Y, Z, x, y$. As expected from the dependence of the color of selenium glasses on annealing temperature, the orange-red glasses showed no correlation of chromaticity with thickness. The values of luminous transmittance were, however, inferred from the measured chromaticity coordinates, on the assumption that all orange-red glasses contained the same absorbing material though produced in varying amounts because of differences in annealing temperature. This assumption was checked by measurement of the luminous transmittance of five of the duplicate orange-red glasses on the Martens photometer.

\section{Results}

\subsection{Spectral Transmittances of Master Set No. 3}

Tables 2 through 6 show for every $10 \mathrm{~m} \mu$ the results of measuring the spectral transmittances of the five glasses of master set No. 3 and applying the routine corrections. Table 7 shows the values of spectral transmittance obtained at the wavelengths of the emission lines of mercury and helium.

TABLE 2. Spectral transmittance of glass filter 2101, master set No. 3, as measured on the indicated spectrophotometers

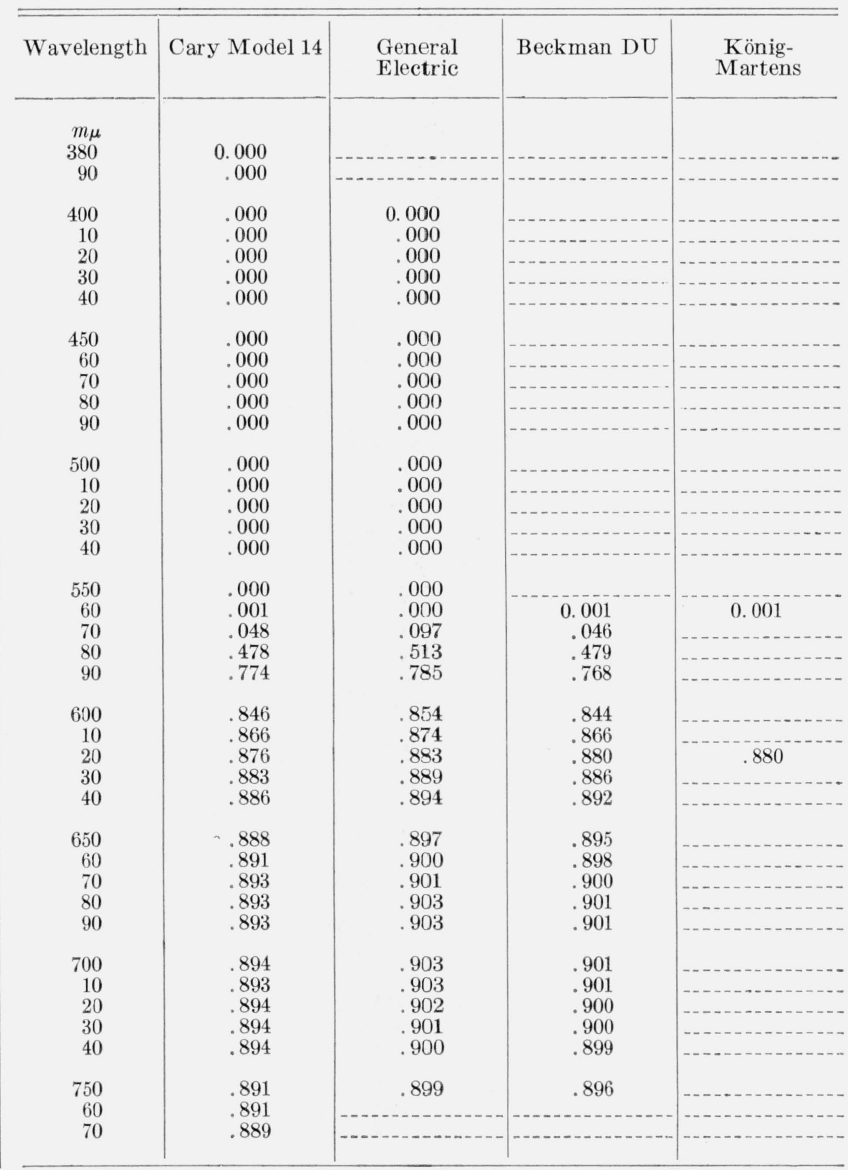




\subsection{Corrections Developed From Present Study}

\section{a. Lead Sulfide Cell Corrections for Cary Data}

The results of the measurements, given above, for the Cary indicate the data obtained by the lead sulfide cell without corrections. The values corrected for discrepancies between the data taken with the multiplier phototube and the lead sulfide cell are higher by the factor 1.003 from 600 to $770 \mathrm{m \mu}$.

\section{b. Slit Width, Inertia, and Back-Reflectance on GE Data}

The data listed in tables 2 to 6 show for the General Electric recording spectrophotometer the results of the measurements taking into consideration only the routine corrections for 100 percent, zero, and wavelength scale. In table 8 are listed the results from the GE corrected for the above routine errors plus the corrections for inertia, slit width, and back reflectance.

\subsection{Derivation of Adopted Values of Spectral Transmittance of Master Set No. 3}

The finally adopted data of spectral transmittance for the five filters of master set No. 3 were derived as a weighted mean of three sets of measurements:

TABLE 3. Spectral transmittance of glass filter 2102, master set No. 3, as measured on the indicated spectrophotometers

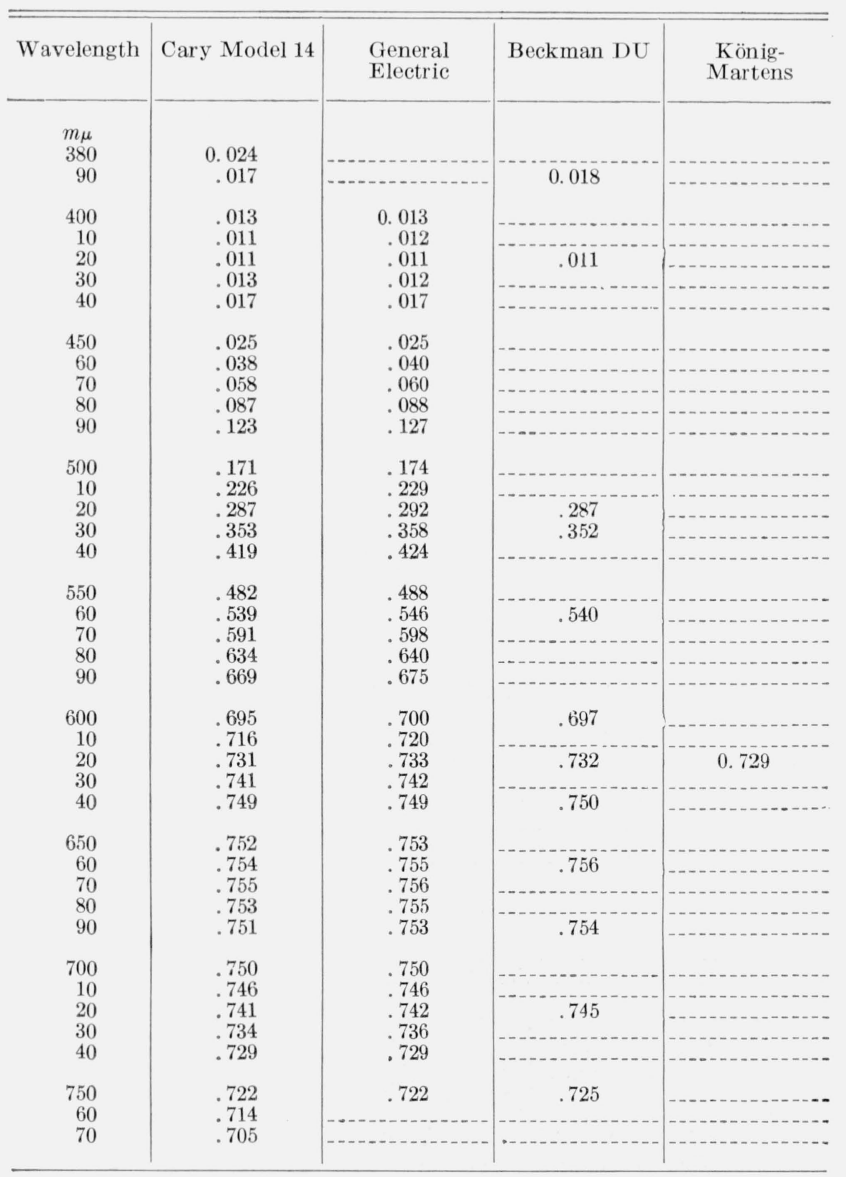

(1) the Cary data with lead sulfide cell correction, (2) the GE with routine corrections and corrections for inertia, slit width, and back reflectance, and (3) the Beckman DU. Where measured data were lacking, as in the case witb the Beckman DU, values of spectral transmittance were interpolated. The weights used for the data were 4 (Cary), 3 (GE), and 3 (Beckman DU) for the filters designated 2101, 2102,2103 , and 2105. In the case of the filter designated 2104, however, little data were taken by the Beckman DU and the assigned weights were 4 (Cary), 4 (GE), and 2 (Beckman DU). The adopted weighted mean data of spectral transmittance for the five filters of master set No. 3 are listed in table 9 .

\subsection{Derivation of Adopted Tristimulus Values and Chromaticity Coordinates}

The spectral transmittance data listed in table 9 were processed by means of an IBM 704 high-speed digital computer which converts spectral-transmittance data into colorimetric terms for $10-\mathrm{m} \mu$ summation intervals by means of the tristimulus functions, $\bar{x}, \bar{y}, \bar{z}$, adopted by the CIE in 1931. What is desired are tristimulus values and chromaticity coordinates based on the CIE tristimulus functions

TABLE 4. Spectral transmittance of glass filter 2103, master set No. 3, as measured on the indicated spectrophotometers

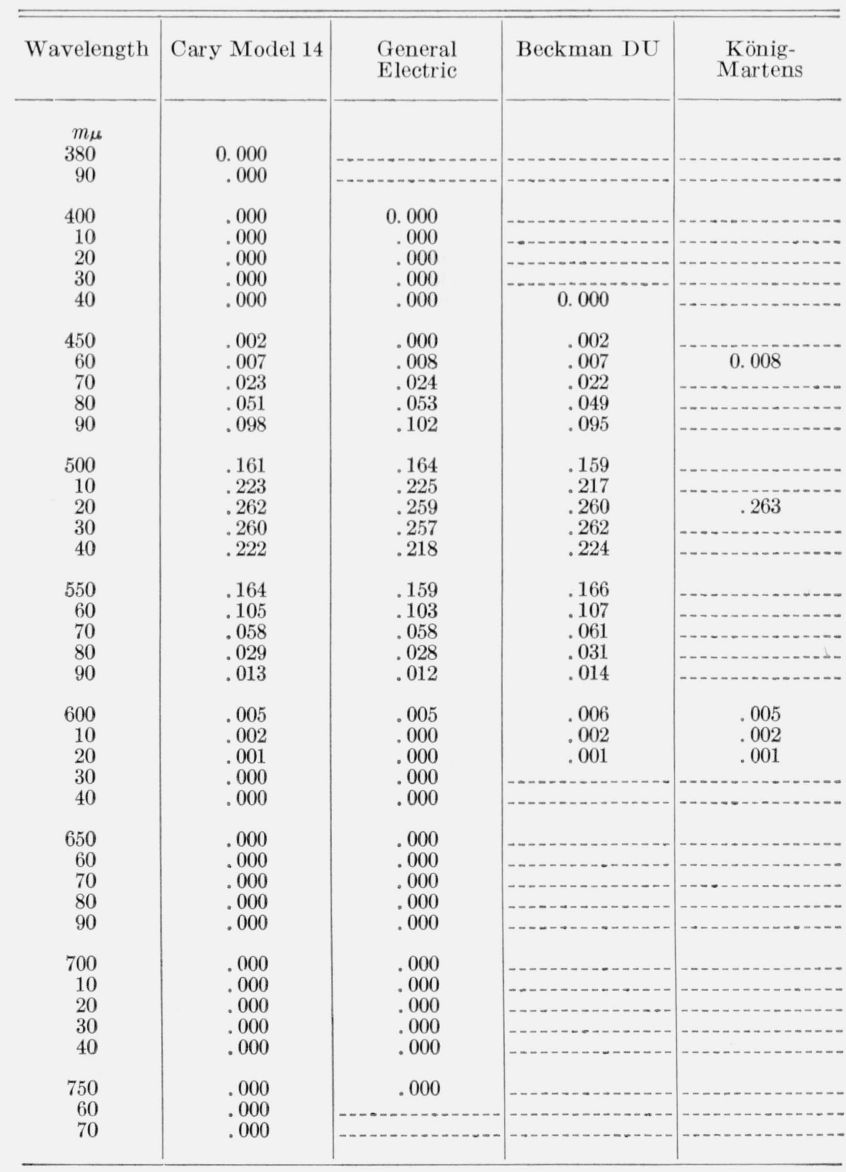


TABLE 5. Spectral transmittance of glass filter 2104, master set No. 3, as measured on the indicated spectrophotometers

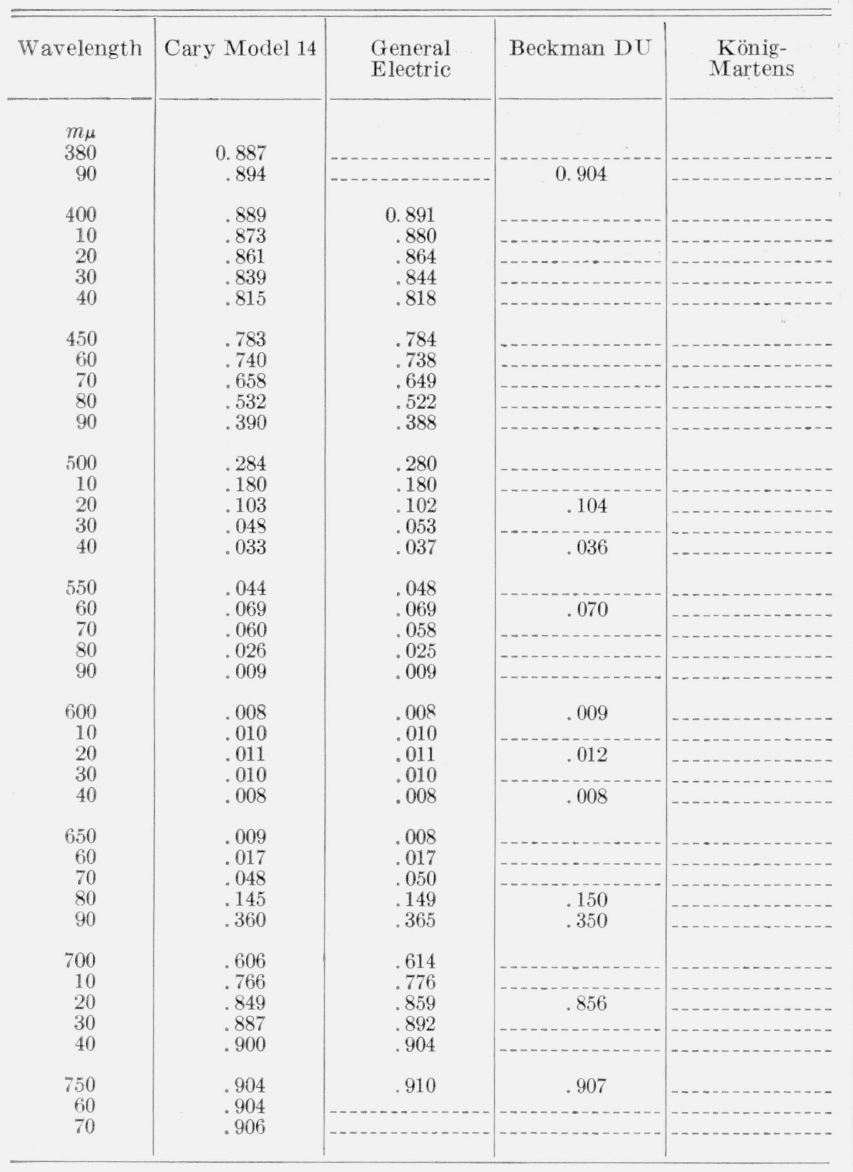

TABLE 6. Spectral transmiltance of glass filter 2105, master set No. 3, as measured on the indicated spectrophotometers

\begin{tabular}{|c|c|c|c|c|}
\hline Wavelength & Cary Model 14 & $\begin{array}{l}\text { General } \\
\text { Electric }\end{array}$ & Beckman DU & $\begin{array}{l}\text { König- } \\
\text { Martens }\end{array}$ \\
\hline $\begin{array}{r}m \mu \\
380 \\
90\end{array}$ & $\begin{array}{r}0.022 \\
.088\end{array}$ & & $\begin{array}{r}0.024 \\
.089\end{array}$ & \\
\hline $\begin{array}{r}400 \\
10 \\
20 \\
30 \\
40\end{array}$ & $\begin{array}{l}.247 \\
.401 \\
.484 \\
.544 \\
.602\end{array}$ & $\begin{array}{r}0.284 \\
.418 \\
.496 \\
.557 \\
.615\end{array}$ & $\begin{array}{l}.253 \\
.406 \\
.487 \\
.547 \\
.608\end{array}$ & \\
\hline $\begin{array}{r}450 \\
60\end{array}$ & .657 & .664 & $\begin{array}{r}.659 \\
696\end{array}$ & \\
\hline $\begin{array}{l}00 \\
70\end{array}$ & $\begin{array}{l}.090 \\
.708\end{array}$ & $\begin{array}{l}.701 \\
.713\end{array}$ & $\begin{array}{l}.696 \\
.713\end{array}$ & 0.717 \\
\hline $\begin{array}{l}80 \\
90\end{array}$ & .700 & $\begin{array}{l}.703 \\
.683\end{array}$ & $\begin{array}{l}.705 \\
.684\end{array}$ & 年 \\
\hline 500 & 658 & 659 & 662 & \\
\hline 10 & .624 & 626 & .629 & $\ldots$ \\
\hline 20 & .590 & 592 & .594 & \\
\hline 30 & .565 & .568 & $\begin{array}{l}.566 \\
568\end{array}$ & .565 \\
\hline 40 & .570 & .575 & .568 & \\
\hline 550 & .603 & . 609 & .605 & \\
\hline $\begin{array}{l}60 \\
70\end{array}$ & .621 & $\begin{array}{l}620 \\
579\end{array}$ & .624 & 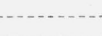 \\
\hline 80 & .583 & $\begin{array}{l}.579 \\
.504\end{array}$ & .514 & 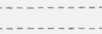 \\
\hline 90 & .446 & .452 & .452 & \\
\hline 600 & .444 & .449 & .445 & \\
\hline 10 & .455 & 460 & .458 & \\
\hline 20 & .459 & .463 & .462 & .462 \\
\hline $\begin{array}{l}30 \\
40\end{array}$ & $\begin{array}{l}.453 \\
.443\end{array}$ & $\begin{array}{l}.457 \\
.448\end{array}$ & $\begin{array}{l}.457 \\
.446\end{array}$ & .448 \\
\hline 650 & .448 & 453 & 450 & \\
\hline 60 & .479 & 484 & .478 & \\
\hline 70 & .540 & .546 & .534 & \\
\hline 80 & .628 & 633 & .623 & \\
\hline 90 & .717 & .721 & . 714 & \\
\hline 700 & .788 & .794 & .788 & \\
\hline 10 & .831 & .839 & .832 & \\
\hline $\begin{array}{l}20 \\
30\end{array}$ & $\begin{array}{l}.857 \\
.872\end{array}$ & $\begin{array}{l}.864 \\
.878\end{array}$ & $\begin{array}{l}.860 \\
.874\end{array}$ & \\
\hline 40 & .880 & .886 & .883 & \\
\hline 750 & .886 & 891 & .889 & \\
\hline $\begin{array}{l}60 \\
70\end{array}$ & $\begin{array}{l}.890 \\
.895\end{array}$ & & & \\
\hline & & & & \\
\hline
\end{tabular}

TABLE 7. Supplementary spectral transmittance measurements of master set No. 3 on the indicated filters and spectrophotometers

\begin{tabular}{|c|c|c|c|c|c|c|c|c|c|c|c|c|c|}
\hline \multirow{2}{*}{$\begin{array}{l}\text { Wave- } \\
\text { length }\end{array}$} & \multirow{2}{*}{ Element } & \multicolumn{3}{|c|}{ Filter 2101} & \multicolumn{3}{|c|}{ Filter 2102} & \multicolumn{3}{|c|}{ Filter 2104} & \multicolumn{3}{|c|}{ Filter 2105} \\
\hline & & $\begin{array}{c}\text { Cary* } \\
\text { Model } 14\end{array}$ & $\begin{array}{l}\text { Beckman } \\
\text { DU }\end{array}$ & $\begin{array}{l}\text { König- } \\
\text { Martens }\end{array}$ & $\begin{array}{c}\text { Cary* }^{*} \\
\text { Model } 14\end{array}$ & $\begin{array}{c}\text { Beckman } \\
\text { DU }\end{array}$ & $\begin{array}{l}\text { König- } \\
\text { Martens }\end{array}$ & $\begin{array}{c}\text { Cary* } \\
\text { Model } 14\end{array}$ & $\underset{\mathrm{DU}}{\text { Beckman }}$ & $\begin{array}{l}\text { König- } \\
\text { Martens }\end{array}$ & $\begin{array}{c}\text { Cary* } \\
\text { Model } 14\end{array}$ & $\begin{array}{l}\text { Beckman } \\
\text { DU }\end{array}$ & $\begin{array}{l}\text { König- } \\
\text { Martens }\end{array}$ \\
\hline $\begin{array}{l}m \mu \\
404.7\end{array}$ & Mercury & & & & 0.012 & 0.013 & & 0.882 & 0.893 & & & & \\
\hline 435.8 & Mercury & & & $\cdots$ & .015 & .015 & 0.015 & .826 & .833 & & & & \\
\hline $\begin{array}{l}471.3 \\
491.6\end{array}$ & $\begin{array}{l}\text { Helium_-_- } \\
\text { Mercury }\end{array}$ & & & & & & & $\begin{array}{r}646 \\
365\end{array}$ & $\begin{array}{r}645 \\
374\end{array}$ & & & & \\
\hline 501.6 & Helium... & & & & .181 & 179 & & .265 & 270 & & & & \\
\hline 546.1 & Mercury _.. & & & & .457 & .456 & ..... & .036 & .038 & & & & $\ldots$ \\
\hline $\begin{array}{l}578.0 \\
587.6\end{array}$ & $\begin{array}{l}\text { Mercury } \\
\text { Helium }\end{array}$ & 0.374 & & 0.393 & $\begin{array}{l}.627 \\
.663\end{array}$ & $\begin{array}{l}.625 \\
.659\end{array}$ & - & .032 & .032 & & & & \\
\hline 595.0 & $\left({ }^{* *}\right) \ldots$ & 821 & 0.824 & & & & & .007 & & 0.008 & 0.440 & & 0.441 \\
\hline 645.0 & $(* *)$ & & & & & & & .008 & & .008 & & & \\
\hline 667.8 & Helium.- & & & & & & & .038 & .037 & & & & \\
\hline 706.5 & Helium_.. & & & & & & & .709 & .726 & & & & \\
\hline
\end{tabular}

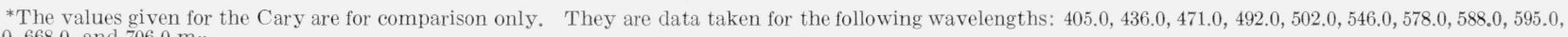
$645.0,668.0$, and $706.0 \mathrm{~m} \mu$

**Measured with the continuum of the tungsten source.

for $1 \mathrm{~m} \mu$ summation intervals. These data were derived in the following manner. Tristimulus values and chromaticity coordinates were available from measurements of spectral transmittance made with the Cary for both 1- and $10-\mathrm{m} \mu$ summation intervals but for the Hardy values of the tristimulus functions.
The following derivation will serve as an example:

$$
\begin{aligned}
& X_{1}^{\prime}-X_{10}^{\prime}=\Delta X \\
& X_{10}+\Delta X=X_{1}
\end{aligned}
$$

where $X_{1}^{\prime}$ and $X_{10}^{\prime}$ are the $X$ tristimulus values com- 
TABLE 8. Corrected spectral transmittance of master set No. 3 Measurements made on the General Electric spectrophotometer

\begin{tabular}{|l|l|l|l|l|l}
\hline Wavelength & Filter 2101 & Filter 2102 & Filter 2103 & Filter 2194 & Filter 2105 \\
\hline
\end{tabular}

\begin{tabular}{|c|c|c|c|c|c|}
\hline $\begin{array}{l}m \mu \\
400\end{array}$ & 0.000 & 0.013 & 0.000 & 0.891 & 0. 272 \\
\hline 10 & .000 & .012 & .000 & .878 & .415 \\
\hline 20 & .000 & .011 & .000 & .863 & .492 \\
\hline 30 & .000 & .012 & .000 & .843 & .552 \\
\hline 40 & .000 & .016 & .000 & .819 & .610 \\
\hline 450 & .000 & .024 & .000 & .786 & .661 \\
\hline 60 & .000 & .038 & .006 & .743 & .698 \\
\hline 70 & .000 & .058 & .022 & .658 & .712 \\
\hline 80 & .000 & .086 & .049 & .532 & .702 \\
\hline 90 & .000 & .123 & .097 & .394 & .684 \\
\hline 500 & .000 & .170 & .160 & .289 & .661 \\
\hline 10 & .000 & .225 & .223 & .183 & .627 \\
\hline 20 & .000 & .287 & .260 & .107 & .593 \\
\hline 30 & .000 & .354 & .269 & .053 & .566 \\
\hline 40 & .000 & .419 & .222 & .036 & .571 \\
\hline 550 & .030 & .483 & .163 & .046 & .606 \\
\hline 60 & .000 & .541 & .106 & .071 & .623 \\
\hline 70 & .051 & .594 & .667 & .061 & .583 \\
\hline 80 & .503 & .637 & .029 & .025 & .597 \\
\hline 90 & .782 & .672 & .012 & .009 & .449 \\
\hline 600 & .852 & .696 & .005 & .008 & .448 \\
\hline 10 & .872 & .717 & .000 & .010 & .459 \\
\hline 20 & .881 & .731 & .000 & .011 & .462 \\
\hline 30 & .888 & .749 & .000 & .010 & .457 \\
\hline 40 & .892 & .747 & .000 & .008 & .446 \\
\hline 650 & .895 & .751 & .000 & .007 & .449 \\
\hline 60 & .896 & .753 & .000 & .015 & .478 \\
\hline 70 & .898 & .754 & .000 & .042 & .539 \\
\hline 80 & .900 & .753 & .000 & .131 & .627 \\
\hline 90 & .900 & .751 & .000 & .348 & .714 \\
\hline 700 & .900 & .749 & .000 & .606 & .789 \\
\hline 10 & .900 & .744 & .000 & .770 & .835 \\
\hline 20 & .899 & .740 & .000 & .855 & .861 \\
\hline 30 & .898 & .734 & .000 & .890 & .875 \\
\hline 40 & .898 & .727 & .000 & .901 & .883 \\
\hline 750 & .896 & .720 & .000 & .907 & .889 \\
\hline
\end{tabular}

puted from data taken on the Cary for the subscripted summation intervals, based on the tristimulus function of Hardy; $X_{10}$ is the $X$ tristimulus value computed from spectral transmittance data of the adopted weighted mean for $10 \mathrm{~m} \mu$ summation intervals, based on the CIE tristimulus function; and $X_{1}$ is the derived $X$ tristimulus value for the adopted weighted mean for $1 \mathrm{~m} \mu$ summation interval based on the CIE tristimulus function. Similar derivations were made for the $Y$ and $Z$ tristimulus values and the chromaticity coordinates $x, y, z$ were computed in the normal manner. The adopted tristimulus values and chromaticity coordinates are listed in table 10 for the filters of master set No. 3 .

\subsection{Estimates of Uncertainty Both for Master Set No. 3 and for the Duplicates}

\section{a. Master Set No. 3}

The uncertainties of the tristimulus values of the five filters of master set No. 3 were estimated by computing the tristimulus values for each set of adopted values (one for each of the Cary, GE, and Beckman spectrophotometers) and taking the range of these computed values as the estimate. Table 11 shows these ranges, not only for the tristimulus values $(X, Y, Z)$, but also for the chromaticity coordinates $(x, y)$. These ranges correspond roughly to estimates of three times the standard deviations of the adopted values. [12].
TABLE 9. Weighted mean spectral transmittance of master set No. 8

Based on measurements from the Cary Model 14, General Electric, and Beckman DU spectrophotometers

\begin{tabular}{|c|c|c|c|c|c|}
\hline Wavelength & Filter 2101 & Filter 2102 & Filter 2103 & Fiiter 2104 & Filter 2105 \\
\hline $\begin{array}{r}m \mu \\
380 \\
90\end{array}$ & $\begin{array}{r}0.000 \\
.000\end{array}$ & $\begin{array}{r}0.023 \\
.016\end{array}$ & $\begin{array}{r}0.000 \\
.000\end{array}$ & $\begin{array}{r}0.890 \\
.897\end{array}$ & $\begin{array}{r}0.023 \\
.086\end{array}$ \\
\hline $\begin{array}{r}400 \\
10 \\
20 \\
30 \\
40\end{array}$ & $\begin{array}{l}.000 \\
.000 \\
.000 \\
.000 \\
.000\end{array}$ & $\begin{array}{l}.013 \\
.011 \\
.011 \\
.013 \\
.017\end{array}$ & $\begin{array}{l}.000 \\
.000 \\
.000 \\
.000 \\
.000\end{array}$ & $\begin{array}{l}.892 \\
.877 \\
.863 \\
.842 \\
.818\end{array}$ & $\begin{array}{l}.256 \\
.407 \\
.487 \\
.547 \\
.606\end{array}$ \\
\hline $\begin{array}{r}450 \\
60 \\
70 \\
80 \\
90\end{array}$ & $\begin{array}{l}.000 \\
.000 \\
.000 \\
.000 \\
.000\end{array}$ & $\begin{array}{l}.025 \\
.038 \\
.058 \\
.087 \\
.123\end{array}$ & $\begin{array}{l}.002 \\
.007 \\
.022 \\
.050 \\
.097\end{array}$ & $\begin{array}{l}.785 \\
.742 \\
.659 \\
.533 \\
.392\end{array}$ & $\begin{array}{l}.659 \\
.696 \\
.711 \\
.702 \\
.682\end{array}$ \\
\hline $\begin{array}{r}500 \\
10 \\
20 \\
30 \\
40\end{array}$ & $\begin{array}{l}.000 \\
.000 \\
.000 \\
.000 \\
.000\end{array}$ & $\begin{array}{l}.170 \\
.225 \\
.287 \\
.353 \\
.420\end{array}$ & $\begin{array}{l}.160 \\
.221 \\
.261 \\
.261 \\
.223\end{array}$ & $\begin{array}{l}.286 \\
.181 \\
.105 \\
.050 \\
.035\end{array}$ & $\begin{array}{l}.660 \\
.626 \\
.592 \\
.566 \\
.570\end{array}$ \\
\hline $\begin{array}{r}550 \\
60 \\
70 \\
80 \\
90\end{array}$ & $\begin{array}{l}.000 \\
.001 \\
.049 \\
.489 \\
.776\end{array}$ & $\begin{array}{l}.484 \\
.540 \\
.593 \\
.637 \\
.671\end{array}$ & $\begin{array}{l}.164 \\
.106 \\
.059 \\
.029 \\
.013\end{array}$ & $\begin{array}{l}.044 \\
.069 \\
.059 \\
.025 \\
.008\end{array}$ & $\begin{array}{l}.605 \\
.623 \\
.584 \\
.510 \\
.449\end{array}$ \\
\hline $\begin{array}{r}600 \\
10 \\
20 \\
30 \\
40\end{array}$ & $\begin{array}{l}.847 \\
.869 \\
.880 \\
.887 \\
.891\end{array}$ & $\begin{array}{l}.696 \\
.718 \\
.732 \\
.742 \\
.750\end{array}$ & $\begin{array}{l}.005 \\
.002 \\
.001 \\
.000 \\
.000\end{array}$ & $\begin{array}{l}.008 \\
.010 \\
.011 \\
.010 \\
.008\end{array}$ & $\begin{array}{l}.446 \\
.458 \\
.462 \\
.456 \\
.445\end{array}$ \\
\hline $\begin{array}{r}650 \\
60 \\
70 \\
80 \\
90\end{array}$ & $\begin{array}{l}.893 \\
.896 \\
.898 \\
.899 \\
.899\end{array}$ & $\begin{array}{l}.754 \\
.756 \\
.756 \\
.755 \\
.753\end{array}$ & $\begin{array}{l}.000 \\
.000 \\
.000 \\
.000 \\
.000\end{array}$ & $\begin{array}{l}.008 \\
.016 \\
.044 \\
.140 \\
.354\end{array}$ & $\begin{array}{l}.449 \\
.479 \\
.539 \\
.627 \\
.716\end{array}$ \\
\hline $\begin{array}{r}700 \\
10 \\
20 \\
30 \\
40\end{array}$ & $\begin{array}{l}.899 \\
.899 \\
.898 \\
.898 \\
.898\end{array}$ & $\begin{array}{l}.752 \\
.748 \\
.743 \\
.736 \\
.730\end{array}$ & $\begin{array}{l}.000 \\
.000 \\
.000 \\
.000 \\
.000\end{array}$ & $\begin{array}{l}.607 \\
.770 \\
.854 \\
.891 \\
.902\end{array}$ & $\begin{array}{l}.790 \\
.834 \\
.860 \\
.874 \\
.883\end{array}$ \\
\hline $\begin{array}{r}750 \\
60 \\
70\end{array}$ & $\begin{array}{l}.895 \\
.896 \\
.894\end{array}$ & $\begin{array}{l}.724 \\
.716 \\
.707\end{array}$ & $\begin{array}{l}.000 \\
.000 \\
.000\end{array}$ & $\begin{array}{l}.907 \\
.907 \\
.906\end{array}$ & $\begin{array}{l}.889 \\
.893 \\
.897\end{array}$ \\
\hline
\end{tabular}

TABLE 10. Adopted tristimulus values $\mathrm{X}, \mathrm{Y}, \mathrm{Z}$ and chromaticity coordinates $\mathrm{x}, \mathrm{y}, \mathrm{z}$ for master set No. 3

\begin{tabular}{|c|c|c|c|c|c|c|}
\hline \multicolumn{7}{|c|}{ Source $A$} \\
\hline Filter & $X$ & $Y$ & $Z$ & $x$ & $y$ & $z$ \\
\hline $\begin{array}{l}2101 \\
2102 \\
2103 \\
2104 \\
2105\end{array}$ & $\begin{array}{r}68.665 \\
70.395 \\
3.197 \\
6.714 \\
54.893\end{array}$ & $\begin{array}{r}36.874 \\
55.365 \\
9.074 \\
5.812 \\
53.882\end{array}$ & $\begin{array}{r}0.033 \\
2.301 \\
1.302 \\
23.493 \\
23.069\end{array}$ & $\begin{array}{r}0.6504 \\
.5497 \\
.2355 \\
.1864 \\
.4163\end{array}$ & $\begin{array}{r}0.3493 \\
.4323 \\
.6685 \\
.1614 \\
.4087\end{array}$ & $\begin{array}{r}0.0003 \\
.0180 \\
.0959 \\
.6522 \\
.1750\end{array}$ \\
\hline \multicolumn{7}{|c|}{ Source $B$} \\
\hline $\begin{array}{l}2101 \\
2102 \\
2103 \\
2104 \\
2105\end{array}$ & $\begin{array}{r}50.977 \\
56.302 \\
3.483 \\
12.832 \\
51.390\end{array}$ & $\begin{array}{r}28.293 \\
50.760 \\
10.782 \\
7.975 \\
55.598\end{array}$ & $\begin{array}{r}0.028 \\
4.369 \\
2.195 \\
59.742 \\
54.736\end{array}$ & $\begin{array}{r}0.6429 \\
.5053 \\
.2116 \\
.1593 \\
.3179\end{array}$ & $\begin{array}{r}0.3568 \\
.4555 \\
.6550 \\
.0990 \\
.3434\end{array}$ & $\begin{array}{r}0.0004 \\
.0392 \\
.1334 \\
.7417 \\
.3386\end{array}$ \\
\hline \multicolumn{7}{|c|}{ Source $C$} \\
\hline $\begin{array}{l}2101 \\
2102 \\
2103 \\
2104 \\
2105\end{array}$ & $\begin{array}{r}45.019 \\
51.458 \\
3.556 \\
17.216 \\
51.830\end{array}$ & $\begin{array}{r}25.312 \\
48.886 \\
11.304 \\
9.099 \\
56.142\end{array}$ & $\begin{array}{r}0.025 \\
5.566 \\
2.642 \\
84.340 \\
75.444\end{array}$ & $\begin{array}{r}0.6399 \\
.4859 \\
.2032 \\
.1556 \\
.2826\end{array}$ & $\begin{array}{r}0.3598 \\
.4616 \\
.6459 \\
.0822 \\
.3561\end{array}$ & $\begin{array}{r}0.0004 \\
.0526 \\
.1510 \\
.7622 \\
.4113\end{array}$ \\
\hline
\end{tabular}


TABLE 11. Range $(\Delta \mathrm{X}, \Delta \mathrm{Y}, \Delta \mathrm{Z})$ for the tristimulus values of the indicated filters of master set No. 3; also ranges ( $\Delta \mathrm{x}, \Delta \mathrm{y}, \Delta \mathrm{z})$ for the chromaticity coordinates

\begin{tabular}{|c|c|c|c|c|c|c|c|c|c|}
\hline \multirow{2}{*}{ Filter } & \multicolumn{3}{|c|}{ Source $A$} & \multicolumn{3}{|c|}{ Source $B$} & \multicolumn{3}{|c|}{ Source $C$} \\
\hline & $\Delta X$ & $\Delta Y$ & $\Delta Z$ & $\Delta X$ & $\Delta Y$ & $\Delta Z$ & $\Delta X$ & $\Delta Y$ & $\Delta Z$ \\
\hline \multirow[t]{2}{*}{$\begin{array}{l}2101 \\
2102 \\
2103 \\
2104 \\
2105\end{array}$} & $\begin{array}{r}0.62 \\
.11 \\
.13 \\
.15 \\
.19\end{array}$ & $\begin{array}{r}0.49 \\
.02 \\
.13 \\
.23 \\
.20\end{array}$ & $\begin{array}{l}0.00 \\
.02 \\
.03 \\
.14 \\
.16\end{array}$ & $\begin{array}{r}0.53 \\
.07 \\
.12 \\
.18 \\
.20\end{array}$ & $\begin{array}{r}0.42 \\
.02 \\
.11 \\
.27 \\
.22\end{array}$ & $\begin{array}{r}0.00 \\
.05 \\
.08 \\
.35 \\
.43\end{array}$ & $\begin{array}{r}0.49 \\
.06 \\
.11 \\
.20 \\
.21\end{array}$ & $\begin{array}{r}0.49 \\
.01 \\
.10 \\
.28 \\
.22\end{array}$ & $\begin{array}{r}0.00 \\
.05 \\
.10 \\
.50 \\
.61\end{array}$ \\
\hline & $\Delta x$ & $\Delta y$ & $\Delta z$ & $\Delta x$ & $\Delta y$ & $\Delta z$ & $\Delta x$ & $\Delta y$ & $\Delta z$ \\
\hline $\begin{array}{l}2101 \\
2102 \\
2103 \\
2104 \\
2105\end{array}$ & $\begin{array}{r}0.0009 \\
.0002 \\
.0053 \\
.0019 \\
.0003\end{array}$ & $\begin{array}{r}0.0009 \\
.0003 \\
.0040 \\
.0034 \\
.0004\end{array}$ & $\begin{array}{r}0.0000 \\
.0001 \\
.0036 \\
.0057 \\
.0007\end{array}$ & $\begin{array}{r}0.0010 \\
.0001 \\
.0048 \\
.0008 \\
.0004\end{array}$ & $\begin{array}{r}0.0010 \\
.0004 \\
.0035 \\
.0025 \\
.0007\end{array}$ & $\begin{array}{r}0.0000 \\
.0006 \\
.0046 \\
.0032 \\
.0012\end{array}$ & $\begin{array}{r}0.0011 \\
.0001 \\
.0046 \\
.0005 \\
.0004\end{array}$ & $\begin{array}{r}0.0011 \\
.0005 \\
.0041 \\
.0019 \\
.0008\end{array}$ & $\begin{array}{r}0.0000 \\
.0006 \\
.0051 \\
.0024 \\
.0012\end{array}$ \\
\hline
\end{tabular}

\section{b. Duplicates}

The ranges found for the chromaticity coordinates of the duplicates by measurement of the limit filters were smaller than the uncertainties of the chromaticity coordinates of the master standard No. 3 for the green filters (2103) and the selective neutral filters (2105). Since the uncertainties of the certified values of these filters would not be significantly reduced by individual measurements of these duplicates, they have been certified as having precisely the same values as their respective master standards from set No. 3.

The ranges found for the chromaticity coordinates of the duplicates of the yellow (2102) and blue (2104) filters, however, were notably larger than the uncertainties of the master standards, and that of the orange.red (2101) duplicates was comparable to the uncertainty of the orange-red master standard. On this account, the chromaticity coordinates of these duplicates were measured relative to the master standard by the CDC visual colorimeter [13] either for source $A$ or $C$ ( $A$ for 2101 and $2104, C$ for 2102 ) whichever made the chromaticity differences most readily perceptible. The certified values of luminous transmittance for all three sources, and those of the chromaticity coordinates for the sources not used in the CDC measurements were inferred by interpolation from computations for $T^{1 / 2}, T$, and $T^{2}$ for the corresponding master standard.

The uncertainties of the certified values of the duplicates are, of course, larger than those of the

TABLE 12. Estimated uncertainties in the tristimulus values X, $\mathrm{Y}, \mathrm{Z}$ and chromaticity coordinates $\mathrm{x}, \mathrm{y}$ certified for the duplicates

\begin{tabular}{|c|c|c|c|c|c|}
\hline \multirow{2}{*}{ Filter } & \multicolumn{3}{|c|}{ Tristimulus values } & \multicolumn{2}{|c|}{$\begin{array}{c}\text { Chromaticity } \\
\text { coordinates }\end{array}$} \\
\hline & $X$ & $Y$ & $Z$ & $x$ & $y$ \\
\hline $\begin{array}{l}2101 \\
2102 \\
2103 \\
2104 \\
2105\end{array}$ & $\begin{array}{r}\% \\
0.6 \\
.2 \\
.2 \\
.2 \\
.4\end{array}$ & $\begin{array}{r}\% \\
0.5 \\
.2 \\
.2 \\
.3 \\
.3\end{array}$ & $\begin{array}{r}\% \\
0.0 \\
.1 \\
.1 \\
.5 \\
.7\end{array}$ & $\begin{array}{l}0.001 \\
.001 \\
.005 \\
.003 \\
.001\end{array}$ & $\begin{array}{r}0.001 \\
.001 \\
.004 \\
.004 \\
.001\end{array}$ \\
\hline
\end{tabular}

corresponding values for the corresponding standard from master set No. 3 (see ranges given in table 11). The estimated uncertainties for the duplicates are given in table 12 . They were estimated as the square root of the sum of the squares of the uncertainties for the master standard and of the additional uncertainties introduced by relating the duplicates to the master standards.

\section{Use of the Set of Color Standards}

The purchaser of a duplicate set of five glass filters for checking the performance of spectrophotometerintegrator systems of color measurement will receive a report giving the tristimulus values, $X, Y, Z$, and chromaticity coordinates, $x, y$, for each filter for each of CIE sources $A, B$, and $C$. It is presumed that he bought them because he has at his disposal a spectrophotometer-integrator system and wished to check its performance, to identify any sources of error, and to correct them, or correct for them, if possible.

\subsection{Calculation of Par Values $\left(\mathrm{X}_{0}, \mathrm{Y}_{0}, \mathrm{Z}_{0}, \mathrm{x}_{0}, \mathrm{y}_{0}\right)$ for a Given Spectrophotometer-Integrator System in Perfect Adjustment}

It should be noted that values certified for each duplicate set refer to slit widths so small that further reduction would not change the values, and that the integrations have been carried out by summation over wavelength intervals so small that further reduction of the interval would not change the values. The spectrophotometer-integrator system at the disposal of the purchaser, however, is characterized by slit widths which the purchaser will have evaluated, and the integrator is characterized by a system which the purchaser will know; that is, it will be by continuous integration equivalent to a summation interval approaching zero, or by a weighted ordinate summation of known wavelength interval, or by a selectedordinate summation of a known number of ordinates, or some other known system. If this spectrophotometer-integrator system is characterized either by slit widths significantly different from zero, or by an 
integrator-summation interval significantly different from zero, or has other permanent defects (such as back reflectance) arising from its design, the system cannot be expected to yield the certified values $(X, Y, Z, x, y)$ for the standard glass filters even if it is in perfect adjustment.

The first step, therefore, is to compute the changes in the certified values for the filters expected to be introduced by use of slit widths or summation intervals significantly greater than zero, and the changes expected to be introduced by other permanent defects (such as back reflectance) arising from the design of the spectrophotometer-integrator system. To assist the purchaser to calculate from the certified value $(X, Y, Z, x, y)$ the values, $X_{0}, Y_{0}$, $Z_{0}, x_{0}, y_{0}$, for the five standard filters that are par for this system, the influence of making the slit width and summation intervals greater than zero have been computed. Table 13 shows the influence of substituting for slits approaching zero width, 5-, 10-, and $15-\mathrm{m} \mu$ slits with triangular slit functions. Note that the influence is far from linear with slit widths, but varies approximately as its square. Table 14 shows the influence of substituting 5-, 10-, and $15-\mathrm{m} \mu$ summation intervals for intervals approaching zero, and table 15 shows the influence of substituting 100,30 , and 10 selected ordinates for weightedordinate summation over intervals of $1 \mathrm{~m} \mu$. Note again that these influences are not linear with the dependent variables; so the influences have to be found from tables 14 and 15 by graphical interpolation. Finally, table 16 shows the changes introduced by back-reflectance errors computed from formula 3. These changes for a spectrophotometerintegrator system based on the GE spectrophotometer may be found by evaluating the maximum error, $E$, in transmittance so introduced and by multiplying the changes in table 16 by the ratio, $E^{*} / 0.026$.

The entries in tables $13,14,15$, and 16 , and the values found from them, are the built-in errors $\Delta X$, $\Delta Y, \Delta Z, \Delta x, \Delta y$; the par values $X_{0}, Y_{0}, Z_{0}, x_{0}, y_{0}$, are found as $X_{0}=X+\Delta X ; x_{0}=x+\Delta x$, and so on.

TABLE 13. Influence of substituting for slits approaching zero width, 5-10- and 15-mu slits with triangular slit functions

\begin{tabular}{|c|c|c|c|c|c|c|c|c|c|c|c|c|c|c|c|}
\hline \multirow{2}{*}{ Filter } & \multicolumn{5}{|c|}{ Source $A$} & \multicolumn{5}{|c|}{ Source $B$} & \multicolumn{5}{|c|}{ Source $C$} \\
\hline & $\Delta X$ & $\Delta Y$ & $\Delta Z$ & $\Delta x$ & $\Delta y$ & $\Delta X$ & $\Delta Y$ & $\Delta Z$ & $\Delta x$ & $\Delta y$ & $\Delta X$ & $\Delta Y$ & $\Delta Z$ & $\Delta x$ & $\Delta y$ \\
\hline \multicolumn{16}{|l|}{2101} \\
\hline $5 \mathrm{~m} \mu$ & -0.032 & +0.008 & 0.000 & -0.00016 & -0.00016 & -0.018 & +0.019 & 0.000 & -0.00023 & +0.00023 & -0.013 & +0.022 & 0.000 & -0.00027 & +0.00027 \\
\hline $10 \mathrm{~m} \mu$ & -.133 & +.035 & .000 & -.00066 & +.00065 & -.074 & +.077 & +.001 & -.00097 & +.00096 & -.054 & +.090 & .000 & -.00110 & +.00110 \\
\hline $15 \mathrm{~m} \mu$ & -.299 & +.078 & .000 & -.00148 & +.00148 & -.167 & +.173 & +.001 & -.00217 & +.00216 & -.121 & +.202 & +.001 & -.00247 & +.00246 \\
\hline \multicolumn{16}{|l|}{2102} \\
\hline $5 \mathrm{~m} \mu$ & -.011 & -.008 & +.005 & -.00002 & -.00001 & -.008 & -.007 & +.010 & -.00005 & -.00004 & -.007 & -.006 & +.013 & -.00006 & -.00006 \\
\hline $10 \mathrm{~m} \mu$ & -.044 & -.034 & +.018 & -.00009 & -.00006 & -.033 & -.027 & +.041 & -.00020 & -.00015 & -.028 & -.023 & +.054 & -.00027 & -. 00023 \\
\hline $15 \mathrm{~m} \mu$ & -.099 & -.076 & +.040 & -.00020 & -.00013 & -.074 & -.060 & †. 091 & -.00047 & -.00035 & -.063 & -.052 & +.122 & -.00062 & -.00053 \\
\hline \multicolumn{16}{|l|}{2103} \\
\hline $5 \mathrm{~m} \mu$ & +. 009 & -.002 & +.004 & +.00047 & -.00068 & +.009 & -.005 & +.010 & +.00034 & -.00083 & +.008 & -.006 & +.013 & +.00030 & -.00093 \\
\hline $10 \mathrm{~m} \mu$ & $\begin{array}{r}+.037 \\
+.083\end{array}$ & -.008 & $\begin{array}{l}+.016 \\
+.037\end{array}$ & +.00193 & -.00281 & $\begin{array}{l}+.035 \\
+.079\end{array}$ & -.021 & +.041 & +.00141 & -.00342 & $\begin{array}{r}+.035 \\
+.078\end{array}$ & -.024 & +.055 & +.00123 & $\begin{array}{l}-.00381 \\
-.00855\end{array}$ \\
\hline $15 \mathrm{~m} \mu$ & †. 083 & -.018 & +.037 & +.00432 & -.00630 & +.079 & -.046 & +.092 & †. 00316 & -.00769 & †. 078 & -.054 & +.125 & +.00274 & -.00855 \\
\hline \multicolumn{16}{|l|}{2104} \\
\hline $\begin{array}{l}5 \mathrm{~m} \mu \\
10 \mathrm{~m} \mu\end{array}$ & +.006 & 十. 012 & -.010 & +.00013 & +.00030 & .000 & +.013 & -.026 & +.00004 & +.00018 & -.002 & +.013 & -.036 & +.00001 & +.00014 \\
\hline $15 \mathrm{~m} \mu$ & $\begin{array}{r}+.020 \\
+.060\end{array}$ & $\begin{array}{r}+.050 \\
+.114\end{array}$ & $\begin{array}{l}-.041 \\
-.091\end{array}$ & $\begin{array}{l}+.00054 \\
+.00123\end{array}$ & $\begin{array}{r}+.00124 \\
+.00280\end{array}$ & $\begin{array}{r}+.004 \\
+.010\end{array}$ & $\begin{array}{l}+.055 \\
+.125\end{array}$ & $\begin{array}{l}-.106 \\
-.237\end{array}$ & $\begin{array}{r}+.00014 \\
+.00033\end{array}$ & $\begin{array}{r}+.00015 \\
+.00169\end{array}$ & $\begin{array}{l}-.001 \\
-.014\end{array}$ & $\begin{array}{r}+.056 \\
+.127\end{array}$ & $\begin{array}{l}-.147 \\
-.331\end{array}$ & $\begin{array}{r}+.00007 \\
+.00017\end{array}$ & $\begin{array}{r}+.00058 \\
+.00132\end{array}$ \\
\hline \multicolumn{16}{|c|}{ 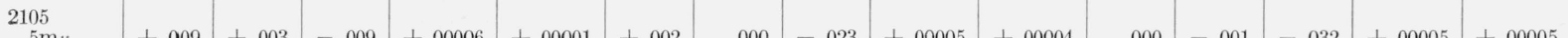 } \\
\hline $5 \mathrm{~m} \mu$ & +.009 & +. 003 & -.009 & +.00006 & +.00001 & +.002 & .000 & -.023 & +.00005 & +.00004 & .000 & -.001 & -.032 & +.00005 & +.00005 \\
\hline $10 \mathrm{~m} \mu$ & +.037 & +.012 & -.039 & +.00025 & +.00006 & +.009 & +.001 & -.096 & +.00022 & +.00019 & -.002 & -.003 & -.133 & +.00020 & +.00021 \\
\hline $15 \mathrm{~m} \mu$ & +.082 & +.027 & -.088 & +.00056 & +.00014 & +.021 & +.003 & -.218 & +.00051 & +.00043 & -.006 & -.006 & -.302 & +.00045 & +.00049 \\
\hline
\end{tabular}

TABLE 14. Influence of substituting 5-, 10-, and 15-mu summation intervals for intervals approaching zero

\begin{tabular}{|c|c|c|c|c|c|c|c|c|c|c|c|c|c|c|c|}
\hline \multirow{2}{*}{ Filter } & \multicolumn{5}{|c|}{ Source $A$} & \multicolumn{5}{|c|}{ Source $B$} & \multicolumn{5}{|c|}{ Source $C$} \\
\hline & $\Delta X$ & $\Delta Y$ & $\Delta Z$ & $\Delta x$ & $\Delta y$ & $\Delta X$ & $\Delta Y$ & $\Delta Z$ & $\Delta x$ & $\Delta y$ & $\Delta X$ & $\Delta Y$ & $\Delta Z$ & $\Delta x$ & $\Delta y$ \\
\hline $\begin{array}{l}2101 \\
5 \mathrm{~m} \mu \\
10 \mathrm{~m} \mu \\
15 \mathrm{~m} \mu\end{array}$ & $\begin{array}{r}+0.028 \\
+.037 \\
-.141\end{array}$ & $\begin{array}{r}+0.015 \\
+.028 \\
-.145\end{array}$ & $\begin{array}{r}0.000 \\
.000 \\
-.001\end{array}$ & $\begin{array}{r}0.00000 \\
-.00005 \\
+.00044\end{array}$ & $\begin{array}{r}0.00000 \\
+.00005 \\
-.00043\end{array}$ & $\begin{array}{r}+0.020 \\
+.027 \\
-.144\end{array}$ & $\begin{array}{r}+0.012 \\
+.021 \\
-.128\end{array}$ & $\begin{array}{r}0.000 \\
.000 \\
.000\end{array}$ & $\begin{array}{r}0.00000 \\
-.00004 \\
+.00040\end{array}$ & $\begin{array}{r}0.00000 \\
+.00004 \\
-.00040\end{array}$ & $\begin{array}{r}+0.019 \\
+.025 \\
-.118\end{array}$ & $\begin{array}{r}+0.010 \\
+.019 \\
-.106\end{array}$ & $\begin{array}{r}0.000 \\
.000 \\
.000\end{array}$ & $\begin{array}{r}0.00000 \\
-.00004 \\
+.00037\end{array}$ & $\begin{array}{r}0.00000 \\
+\quad .00004 \\
-\quad .00037\end{array}$ \\
\hline $\begin{array}{l}2102 \\
5 \mathrm{~m} \mu \\
10 \mathrm{~m} \mu \\
15 \mathrm{~m} \mu\end{array}$ & $\begin{array}{r}+.004 \\
-.001 \\
+.019\end{array}$ & $\begin{array}{l}+.001 \\
-.002 \\
-.007\end{array}$ & $\begin{array}{r}.000 \\
-.002 \\
-.006\end{array}$ & $\begin{array}{r}+.00001 \\
+.00001 \\
+.00012\end{array}$ & $\begin{array}{r}-.00001 \\
.00000 \\
-.00007\end{array}$ & $\begin{array}{l}+.003 \\
-.002 \\
+.010\end{array}$ & $\begin{array}{l}-.001 \\
-.004 \\
-.008\end{array}$ & $\begin{array}{l}-.001 \\
-.004 \\
-.011\end{array}$ & $\begin{array}{r}+.00003 \\
+.00003 \\
+.00013\end{array}$ & $\begin{array}{r}.00000 \\
+.00001 \\
-.00002\end{array}$ & $\begin{array}{l}+.003 \\
-.003 \\
+.022\end{array}$ & $\begin{array}{l}-.001 \\
-.004 \\
-.004\end{array}$ & $\begin{array}{l}-.003 \\
-.006 \\
-.014\end{array}$ & $\begin{array}{r}+.00003 \\
+.00004 \\
+.00019\end{array}$ & $\begin{array}{r}.00000 \\
+.00002 \\
-.00006\end{array}$ \\
\hline $\begin{array}{l}2103 \\
5 \mathrm{~m} \mu \\
10 \mathrm{~m} \mu \\
15 \mathrm{~m} \mu\end{array}$ & $\begin{array}{r}-.001 \\
+.002 \\
+.005\end{array}$ & $\begin{array}{r}-.004 \\
-.000 \\
-.005\end{array}$ & $\begin{array}{l}-.001 \\
-.003 \\
-.003\end{array}$ & $\begin{array}{r}+.00003 \\
+.00013 \\
+.00042\end{array}$ & $\begin{array}{r}-.00002 \\
+.00008 \\
-.00021\end{array}$ & $\begin{array}{l}-.001 \\
+.002 \\
+.006\end{array}$ & $\begin{array}{l}-.005 \\
-.001 \\
-.005\end{array}$ & $\begin{array}{l}-.001 \\
-.005 \\
-.004\end{array}$ & $\begin{array}{r}+.00002 \\
+.00017 \\
+.00037\end{array}$ & $\begin{array}{r}-.00002 \\
+.00014 \\
-.00014\end{array}$ & $\begin{array}{l}-.002 \\
+.001 \\
+.004\end{array}$ & $\begin{array}{l}-.006 \\
-.001 \\
-.007\end{array}$ & $\begin{array}{l}-.001 \\
-.008 \\
-.005\end{array}$ & $\begin{array}{r}+.00003 \\
+.00018 \\
+.00036\end{array}$ & $\begin{array}{r}-.00003 \\
+.00018 \\
-.00015\end{array}$ \\
\hline $\begin{array}{l}2104 \\
5 \mathrm{~m} \mu \\
10 \mathrm{~m} \mu \\
15 \mathrm{~m} \mu\end{array}$ & $\begin{array}{r}+.002 \\
+.002 \\
+.005\end{array}$ & $\begin{array}{l}+.009 \\
+.010 \\
+.003\end{array}$ & $\begin{array}{l}+.003 \\
-.015 \\
-.005\end{array}$ & $\begin{array}{r}-.00003 \\
+.00007 \\
+.00013\end{array}$ & $\begin{array}{r}+.00019 \\
+.00030 \\
+.00007\end{array}$ & $\begin{array}{r}.000 \\
-.004 \\
+.010\end{array}$ & $\begin{array}{l}+.013 \\
+.012 \\
+.004\end{array}$ & $\begin{array}{l}+.002 \\
.041 \\
+.030\end{array}$ & $\begin{array}{r}-.00002 \\
+.00003 \\
+.00004\end{array}$ & $\begin{array}{r}+.00014 \\
+.00019 \\
\quad .00000\end{array}$ & $\begin{array}{l}+.001 \\
-.006 \\
+.019\end{array}$ & $\begin{array}{l}+.014 \\
+.013 \\
+.006\end{array}$ & $\begin{array}{r}+.001 \\
-.057 \\
+.075\end{array}$ & $\begin{array}{r}-.00002 \\
+.00001 \\
+.00002\end{array}$ & $\begin{array}{r}+.00012 \\
+.00016 \\
-.00002\end{array}$ \\
\hline $\begin{array}{l}2105 \\
5 \mathrm{~m} \mu \\
10 \mathrm{~m} \mu \\
15 \mathrm{~m} \mu\end{array}$ & $\begin{array}{r}-.006 \\
-.016 \\
+.005\end{array}$ & $\begin{array}{l}-.007 \\
-.012 \\
-.009\end{array}$ & $\begin{array}{l}-.004 \\
-.033 \\
-.046\end{array}$ & $\begin{array}{r}+.00001 \\
+.00007 \\
+.00019\end{array}$ & $\begin{array}{r}.00000 \\
+.00010 \\
+.00009\end{array}$ & $\begin{array}{l}-.007 \\
-023 \\
-.004\end{array}$ & $\begin{array}{l}-.007 \\
-.013 \\
-.008\end{array}$ & $\begin{array}{l}-.008 \\
-.079 \\
-.078\end{array}$ & $\begin{array}{r}.00000 \\
+.00009 \\
+.00015\end{array}$ & $\begin{array}{r}.00000 \\
+.00016 \\
+.00014\end{array}$ & $\begin{array}{l}-.006 \\
-.026 \\
+.004\end{array}$ & $\begin{array}{l}-.007 \\
-.013 \\
-.010\end{array}$ & $\begin{array}{l}-.012 \\
-.108 \\
-.081\end{array}$ & $\begin{array}{r}.00000 \\
+.00008 \\
+.00015\end{array}$ & $\begin{array}{r}.00000 \\
+.00017 \\
+.00009\end{array}$ \\
\hline
\end{tabular}


'ТАВLE 15. Influence of substituting 100, 30, and 10 selected ordinates for weighted-ordinate summation over intervals of 1 m $\mu$

\begin{tabular}{|c|c|c|c|c|c|c|c|c|c|c|c|c|c|c|c|}
\hline \multirow{2}{*}{ Filter } & \multicolumn{5}{|c|}{ Source $A$} & \multicolumn{5}{|c|}{ Source $B$} & \multicolumn{5}{|c|}{ Source $C$} \\
\hline & $\Delta X$ & $\Delta Y$ & $\Delta Z$ & $\Delta x$ & $\Delta y$ & $\Delta X$ & $\Delta Y$ & $\Delta Z$ & $\Delta x$ & $\Delta y$ & $\Delta X$ & $\Delta Y$ & $\Delta Z$ & $\Delta x$ & $\Delta y$ \\
\hline $\begin{array}{r}2101 \\
100 \\
30 \\
10\end{array}$ & $\begin{array}{r}-0.003 \\
-.003 \\
+.086\end{array}$ & $\begin{array}{r}+0.001 \\
.000 \\
+.027\end{array}$ & $\begin{array}{r}-0.035 \\
-.035 \\
-.035\end{array}$ & $\begin{array}{r}+0.00020 \\
+.00021 \\
+.00034\end{array}$ & $\begin{array}{r}+0.00013 \\
+.00012 \\
-.00001\end{array}$ & $\begin{array}{r}+0.012 \\
+.010 \\
-.084\end{array}$ & $\begin{array}{r}+0.009 \\
+.012 \\
+.042\end{array}$ & $\begin{array}{r}-0.028 \\
-.028 \\
-.028\end{array}$ & $\begin{array}{r}+0.00022 \\
+.00019 \\
-.00048\end{array}$ & $\begin{array}{r}+0.00014 \\
+.00017 \\
+.00084\end{array}$ & $\begin{array}{r}-0.033 \\
-.071 \\
+.045\end{array}$ & $\begin{array}{r}-0.011 \\
-.030 \\
-.089\end{array}$ & $\begin{array}{r}-0.026 \\
-.026 \\
-.026\end{array}$ & $\begin{array}{r}+0.00018 \\
+.00015 \\
+.00129\end{array}$ & $\begin{array}{r}+0.00019 \\
+.00022 \\
-.00092\end{array}$ \\
\hline $\begin{array}{r}2102 \\
100 \\
30 \\
10\end{array}$ & $\begin{array}{l}-.016 \\
+.198 \\
+.525\end{array}$ & $\begin{array}{r}+.005 \\
+.039 \\
+.216\end{array}$ & $\begin{array}{l}-.014 \\
-.042 \\
-.130\end{array}$ & $\begin{array}{r}-.00002 \\
+.00071 \\
+.00147\end{array}$ & $\begin{array}{l}+.00013 \\
-.00035 \\
-.00037\end{array}$ & $\begin{array}{l}+.017 \\
+.155 \\
+.791\end{array}$ & $\begin{array}{l}+.007 \\
+.014 \\
+.118\end{array}$ & $\begin{array}{l}-.027 \\
-.099 \\
-.267\end{array}$ & $\begin{array}{r}+.00017 \\
+.00107 \\
+.00418\end{array}$ & $\begin{array}{l}+.00008 \\
-.00015 \\
-.00155\end{array}$ & $\begin{array}{l}+.004 \\
-.011 \\
+.144\end{array}$ & $\begin{array}{r}-.003 \\
+.011 \\
+.104\end{array}$ & $\begin{array}{r}-.025 \\
-.118 \\
-.354\end{array}$ & $\begin{array}{r}+.00015 \\
+.00044 \\
+.00186\end{array}$ & $\begin{array}{r}+.00007 \\
+.00062 \\
+.00145\end{array}$ \\
\hline $\begin{array}{r}2103 \\
100 \\
30 \\
10\end{array}$ & $\begin{array}{r}-.027 \\
+.354 \\
+1.420\end{array}$ & $\begin{array}{r}.000 \\
+.024 \\
+.295\end{array}$ & $\begin{array}{r}+.010 \\
+.038 \\
+.032\end{array}$ & $\begin{array}{l}-.00170 \\
+.01836 \\
+.06604\end{array}$ & $\begin{array}{l}+.00083 \\
-.01820 \\
-.05697\end{array}$ & $\begin{array}{r}.000 \\
+.133 \\
+1.084\end{array}$ & $\begin{array}{r}-.004 \\
.000 \\
+.113\end{array}$ & $\begin{array}{l}+.025 \\
+.047 \\
-.097\end{array}$ & $\begin{array}{r}-.00030 \\
+.00569 \\
+.04855\end{array}$ & $\begin{array}{l}-.00106 \\
-.00703 \\
-.03451\end{array}$ & $\begin{array}{l}+.018 \\
+.001 \\
-.132\end{array}$ & $\begin{array}{r}.000 \\
+.022 \\
+.123\end{array}$ & $\begin{array}{l}+.043 \\
+.048 \\
-.199\end{array}$ & $\begin{array}{l}+.00035 \\
-.00075 \\
-.00517\end{array}$ & $\begin{array}{r}-.00228 \\
-.00136 \\
+.01484\end{array}$ \\
\hline $\begin{array}{r}2104 \\
100 \\
30 \\
10\end{array}$ & $\begin{array}{r}-.023 \\
-1.103 \\
-3.410\end{array}$ & $\begin{array}{l}-.127 \\
-.406 \\
-.936\end{array}$ & $\begin{array}{r}-.014 \\
-.020 \\
+.052\end{array}$ & $\begin{array}{l}+.00022 \\
-.02370 \\
-.08221\end{array}$ & $\begin{array}{l}-.00280 \\
-.00463 \\
-.00767\end{array}$ & $\begin{array}{r}-.103 \\
-.495 \\
-2.498\end{array}$ & $\begin{array}{r}-.099 \\
-.175 \\
-.836\end{array}$ & $\begin{array}{r}-.012 \\
+.017 \\
+.278\end{array}$ & $\begin{array}{l}-.00085 \\
-.00490 \\
-.02600\end{array}$ & $\begin{array}{r}-.00097 \\
-.00138 \\
-.00690\end{array}$ & $\begin{array}{l}-.148 \\
-.218 \\
-.070\end{array}$ & $\begin{array}{l}-.083 \\
-.156 \\
-.841\end{array}$ & $\begin{array}{r}-.044 \\
-.013 \\
+.324\end{array}$ & $\begin{array}{r}-.00096 \\
-.00144 \\
+.00019\end{array}$ & $\begin{array}{l}-.00055 \\
-.00113 \\
-.00722\end{array}$ \\
\hline $\begin{array}{r}2105 \\
100 \\
30 \\
10\end{array}$ & $\begin{array}{l}+.013 \\
-.195 \\
-.500\end{array}$ & $\begin{array}{l}-.011 \\
-.138 \\
-.356\end{array}$ & $\begin{array}{l}+.010 \\
+.020 \\
+.098\end{array}$ & $\begin{array}{l}+.00006 \\
-.00050 \\
-.00142\end{array}$ & $\begin{array}{l}-.00012 \\
-.00008 \\
-.00035\end{array}$ & $\begin{array}{l}+.002 \\
-.151 \\
-.716\end{array}$ & $\begin{array}{l}-.022 \\
-.042 \\
-.117\end{array}$ & $\begin{array}{l}+.020 \\
+.092 \\
+.300\end{array}$ & $\begin{array}{l}+.00001 \\
-.00074 \\
-.00341\end{array}$ & $\begin{array}{l}-.00014 \\
-.00005 \\
+.00041\end{array}$ & $\begin{array}{l}-.029 \\
-.136 \\
-.148\end{array}$ & $\begin{array}{l}-.024 \\
-.020 \\
-.023\end{array}$ & $\begin{array}{r}+.023 \\
+.135 \\
+.439\end{array}$ & $\begin{array}{l}-.00012 \\
-.00071 \\
-.00123\end{array}$ & $\begin{array}{r}-.00008 \\
-.00008 \\
-.00058\end{array}$ \\
\hline
\end{tabular}

TABLE 16. Changes introduced by back-reflectance errors computed from formula 3

\begin{tabular}{|c|c|c|c|c|c|}
\hline Filter & $\Delta X$ & $\Delta Y$ & $\Delta Z$ & $\Delta x$ & $\Delta y$ \\
\hline \multicolumn{6}{|c|}{ Source $A$} \\
\hline $\begin{array}{l}2101 \\
2102 \\
2103 \\
2104 \\
2105\end{array}$ & $\begin{array}{r}+0.180 \\
+.149 \\
+.001 \\
+.012 \\
+.087\end{array}$ & $\begin{array}{r}+0.093 \\
+.106 \\
+.004 \\
+.003 \\
+.091\end{array}$ & $\begin{array}{r}0.000 \\
+.001 \\
+.001 \\
+.052 \\
+.048\end{array}$ & $\begin{array}{r}+0.00003 \\
+.00007 \\
-.00004 \\
-.00001 \\
-.00005\end{array}$ & $\begin{array}{r}-0.00002 \\
-.00004 \\
+.00004 \\
-.00021 \\
-.00001\end{array}$ \\
\hline
\end{tabular}

Source $B$

\begin{tabular}{l|r|r|r|r|r}
2101 & +0.132 & +0.070 & 0.000 & +0.00002 & -0.00003 \\
2102 & +.117 & +.092 & +.001 & +.00009 & -.00003 \\
2103 & +.002 & +.066 & +.001 & -.00003 & +.00004 \\
2104 & +.027 & +.007 & +.137 & -.00001 & -.00013 \\
2105 & +.085 & +.096 & +.113 & -.00006 & -.00003
\end{tabular}

Source $C$

\begin{tabular}{l|r|r|r|r|r}
2101 & +0.116 & +0.063 & 0.000 & +0.00002 & -0.00002 \\
2102 & +.106 & +.087 & +.001 & +.00011 & -.00002 \\
2103 & +.001 & +.066 & +.001 & -.00002 & +.00005 \\
2104 & +.037 & +.009 & +.195 & -.00001 & -.00010 \\
2105 & +.087 & +.098 & +.154 & -.00005 & -.00003
\end{tabular}

\subsection{Influence of Various Maladjustments}

The spectrophotometer-integrator system of the purchaser is subject to a variety of malfunctions. Some of them are the result of maladjustments, such as failure of the zero and 100 percent points of the photometric scale to be set correctly, or errors in the adjustment of the wavelength scale; others are the result of wear or the accumulation of dust on the surfaces of optical parts which can introduce stray energy; and still others will be of obscure origin, such as temporary misalinement of optical parts due to development of unforeseen thermal gradients, or faulty linkage between spectrophotometer and integrator. By introduction of the five standard glass filters at regular intervals into the schedule of runs, it should be possible to detect the appearance of any significant malfunction and in some cases to identify its cause. To assist the purchaser in his interpreta- tion of deviations of the values read, $X_{r}, Y_{r}, Z_{r}, x_{r}, y_{r}$, from the corresponding par values, $X_{0}, Y_{0}, Z_{0}, x_{0}, y_{0}$, the pattern of influence of several sorts of malfunction on the readings for the five glasses of the set has been computed. These patterns include the influence of uniform displacement of the wavelength scale, of the zero and 100 percent points on the photometric scale, of stray energy, of inertia error, and back-reflectance error.

\section{a. Wavelength Scale}

Table 17 shows the changes in tristimulus values, $X, Y, Z$, and chromaticity coordinates, $x, y$, that would be introduced by a uniform displacement of the wavelength scale by $\pm 1 \mathrm{~m} \mu$ and $\pm 2 \mathrm{~m} \mu$. It will be noted that standard filters 2101 and 2103 (orange-red and green) provide sensitive indications of displacement of wavelength scale. Since the slope of the transmittance curve with wavelength is appreciable for filter 2101 only between 570 and $590 \mathrm{~m} \mu$ (see table 2), this filter responds to wavelength scale displacement only in this spectral region. Filter 2103, however, responds to wavelength scale displacements in two regions: 470 to $520 \mathrm{~m} \mu$ and 530 to $590 \mathrm{~m} \mu$. For both filters the changes in tristimulus values and chromaticity coordinates are substantially linear with wavelength error.

\section{b. Zero of Photometric Scale}

If the instrument by maladjustment wrongly reads zero when the specimen transmittance is really greater than zero, this maladjustment may be called positive displacement of the instrument zero. If the instrument indicates a transmittance of greater than zero when the specimen transmittance is actually zero, this maladjustment may be called negative displacement of the instrument zero. Table 18 shows the changes that would be introduced by a uniform displacement of the instrument zero of the photometric scale by \pm 1.0 and \pm 0.5 percent independent of wavelength. In computing the influence of positive displacements of the instrument zero, negative 
TABLE 17. Changes in tristimulus values, X, Y, Z, and chromaticity coordinates, $\mathrm{x}, \mathrm{y}$, that would be introduced by a uniform displacement of the wavelength scale by $\pm 1 m \mu$ and $\pm 2 m \mu$

\begin{tabular}{|c|c|c|c|c|c|c|c|c|c|c|c|c|c|c|c|}
\hline \multirow{2}{*}{ Filter } & \multicolumn{5}{|c|}{ Source 4} & \multicolumn{5}{|c|}{ Source $B$} & \multicolumn{5}{|c|}{ Source $C$} \\
\hline & $\Delta X$ & $\Delta Y$ & $\Delta Z$ & $\Delta x$ & $\Delta y$ & $\Delta X$ & $\Delta Y$ & $\Delta Z$ & $\Delta x$ & $\Delta y$ & $\Delta X$ & $\Delta Y$ & $\Delta Z$ & $\Delta x$ & $\Delta y$ \\
\hline $\begin{array}{l}2101 \\
+2 \mathrm{~m} \mu \\
+1 \mathrm{~m} \mu \\
-1 \mathrm{~m} \mu \\
-2 \mathrm{~m} \mu\end{array}$ & $\begin{array}{r}+1.582 \\
+.794 \\
-.879 \\
-1.755\end{array}$ & $\begin{array}{r}+1.517 \\
+.751 \\
-.794 \\
-1.573\end{array}$ & $\begin{array}{r}+0.003 \\
+.001 \\
-.002 \\
-.003\end{array}$ & $\begin{array}{r}-0.00404 \\
-.00199 \\
+.00203 \\
+.00404\end{array}$ & $\begin{array}{r}+0.00402 \\
+.00198 \\
-.00202 \\
-.00403\end{array}$ & $\begin{array}{r}+1.435 \\
+.717 \\
-.782 \\
-1.559\end{array}$ & $\begin{array}{r}+1.395 \\
+.687 \\
-.718 \\
-1.418\end{array}$ & $\begin{array}{r}+0.003 \\
+.002 \\
-.001 \\
-.002\end{array}$ & $\begin{array}{r}-0.00474 \\
-.00233 \\
+.00237 \\
+.00470\end{array}$ & $\begin{array}{r}+0.00471 \\
+.00232 \\
-.00236 \\
-.00468\end{array}$ & $\begin{array}{r}+1.363 \\
+.680 \\
-.738 \\
-1.471\end{array}$ & $\begin{array}{r}+1.332 \\
+.655 \\
-.681 \\
-1.344\end{array}$ & $\begin{array}{r}+0.003 \\
+.001 \\
-.001 \\
-.002\end{array}$ & $\begin{array}{r}-0.00501 \\
-.00246 \\
+.00249 \\
+.00495\end{array}$ & $\begin{array}{r}+0.00499 \\
+.00245 \\
-.00248 \\
-.00493\end{array}$ \\
\hline $\begin{array}{l}2102 \\
+2 \mathrm{~m} \mu \\
+1 \mathrm{~m} \mu \\
-1 \mathrm{~m} \mu \\
-2 \mathrm{~m} \mu\end{array}$ & $\begin{array}{l}+.527 \\
+.261 \\
-.275 \\
-.548\end{array}$ & $\begin{array}{r}+.801 \\
+.402 \\
-.396 \\
-.794\end{array}$ & $\begin{array}{l}+.153 \\
+.076 \\
-.071 \\
-.142\end{array}$ & $\begin{array}{l}-.00222 \\
-.00112 \\
+.00105 \\
+.00212\end{array}$ & $\begin{array}{l}+.00124 \\
+.00064 \\
-.00059 \\
-.00120\end{array}$ & $\begin{array}{l}+.512 \\
+253 \\
-.262 \\
-.522\end{array}$ & $\begin{array}{l}+.878 \\
+.442 \\
-.431 \\
-.864\end{array}$ & $\begin{array}{l}+.308 \\
+.150 \\
-.144 \\
-.286\end{array}$ & $\begin{array}{r}-.00306 \\
-.00155 \\
+.000146 \\
+.00294\end{array}$ & $\begin{array}{l}+.00093 \\
+.00051 \\
-.00045 \\
-.00093\end{array}$ & $\begin{array}{l}+.508 \\
+.251 \\
-.258 \\
-.514\end{array}$ & $\begin{array}{l}+.900 \\
+.453 \\
-.441 \\
-.883\end{array}$ & $\begin{array}{l}+.397 \\
+.194 \\
-.187 \\
-.370\end{array}$ & $\begin{array}{l}-.00343 \\
-.00173 \\
+.00164 \\
+.00331\end{array}$ & $\begin{array}{l}+.00062 \\
+.00037 \\
-.000030 \\
-.00065\end{array}$ \\
\hline $\begin{array}{l}2103 \\
+2 \mathrm{~m} \mu \\
+1 \mathrm{~m} \mu \\
-1 \mathrm{~m} \mu \\
-2 \mathrm{~m} \mu\end{array}$ & $\begin{array}{l}-.250 \\
-.124 \\
+.134 \\
+.274\end{array}$ & $\begin{array}{l}-.347 \\
-.166 \\
+.177 \\
+.361\end{array}$ & $\begin{array}{l}+.122 \\
+.061 \\
-.056 \\
-.112\end{array}$ & $\begin{array}{l}-.01060 \\
-.00524 \\
+.0538 \\
+.01075\end{array}$ & $\begin{array}{l}-.00229 \\
-.00098 \\
+.00045 \\
+.00081\end{array}$ & $\begin{array}{l}-.238 \\
-.117 \\
+.128 \\
+.261\end{array}$ & $\begin{array}{l}-.325 \\
-.153 \\
+.165 \\
+.336\end{array}$ & $\begin{array}{l}+.243 \\
+.120 \\
-.110 \\
-.220\end{array}$ & $\begin{array}{r}-.01057 \\
-.00525 \\
+.00535 \\
+.01078\end{array}$ & $\begin{array}{l}-.00720 \\
-.00337 \\
+.00274 \\
+.00529\end{array}$ & $\begin{array}{l}-.226 \\
-.111 \\
+.122 \\
+.250\end{array}$ & $\begin{array}{l}-.306 \\
-.143 \\
+.155 \\
+.317\end{array}$ & $\begin{array}{l}+.311 \\
+.153 \\
-.139 \\
-.278\end{array}$ & $\begin{array}{l}-.01052 \\
-.00524 \\
+.00533 \\
+.01077\end{array}$ & $\begin{array}{r}-.00941 \\
-.00445 \\
+.00379 \\
+.00734\end{array}$ \\
\hline $\begin{array}{l}2104 \\
+2 \mathrm{~m} \mu \\
+1 \mathrm{~m} \mu \\
-1 \mathrm{~m} \mu \\
-2 \mathrm{~m} \mu\end{array}$ & $\begin{array}{l}-.070 \\
-.036 \\
+.036 \\
+.074\end{array}$ & $\begin{array}{l}-.274 \\
-.136 \\
+.130 \\
+.274\end{array}$ & $\begin{array}{l}-.506 \\
-.246 \\
+.237 \\
+.463\end{array}$ & $\begin{array}{l}+.00253 \\
+.00118 \\
-.000110 \\
-.0214\end{array}$ & $\begin{array}{l}-.00388 \\
-.00193 \\
+.00178 \\
+.00388\end{array}$ & $\begin{array}{l}-.193 \\
-.094 \\
+.092 \\
+.181\end{array}$ & $\begin{array}{l}-.403 \\
-.200 \\
+.191 \\
+.399\end{array}$ & $\begin{array}{r}-1.112 \\
-.535 \\
+.523 \\
+1.014\end{array}$ & $\begin{array}{r}+.00102 \\
+.00049 \\
-.00046 \\
-.00089\end{array}$ & $\begin{array}{l}-.00297 \\
-.00148 \\
+.00037 \\
+.0294\end{array}$ & $\begin{array}{l}-.258 \\
-.124 \\
+.121 \\
+.239\end{array}$ & $\begin{array}{l}-.458 \\
-.227 \\
+.218 \\
+.452\end{array}$ & $\begin{array}{r}-1.484 \\
-.712 \\
+.697 \\
+1.349\end{array}$ & $\begin{array}{l}+.00079 \\
+.00038 \\
-.00036 \\
-.00071\end{array}$ & $\begin{array}{r}-.00256 \\
-.00128 \\
+.00119 \\
+.00253\end{array}$ \\
\hline $\begin{array}{l}2105 \\
\quad+2 \mathrm{~m} \mu \\
\quad+1 \mathrm{~m} \mu \\
\quad-1 \mathrm{~m} \mu \\
-2 \mathrm{~m} \mu\end{array}$ & $\begin{array}{l}-.114 \\
-.081 \\
+.071 \\
+.165\end{array}$ & $\begin{array}{l}-.240 \\
-.139 \\
+.135 \\
+.279\end{array}$ & $\begin{array}{l}+.158 \\
+.080 \\
-.077 \\
-.167\end{array}$ & $\begin{array}{l}-.00024 \\
-.00017 \\
+.00013 \\
+.00038\end{array}$ & $\begin{array}{r}-.00122 \\
-.00062 \\
+.00062 \\
+.00126\end{array}$ & $\begin{array}{l}-.061 \\
-.051 \\
+.040 \\
+.096\end{array}$ & $\begin{array}{l}-.252 \\
-.142 \\
+.141 \\
+.285\end{array}$ & $\begin{array}{l}+.486 \\
+.245 \\
-.243 \\
-.515\end{array}$ & $\begin{array}{r}-.00072 \\
-.00042 \\
+.00037 \\
+.00086\end{array}$ & $\begin{array}{l}-.00193 \\
-.00100 \\
+.000101 \\
+.00206\end{array}$ & $\begin{array}{l}-.011 \\
-.024 \\
+.012 \\
+.039\end{array}$ & $\begin{array}{l}-.251 \\
-.141 \\
+.141 \\
+.282\end{array}$ & $\begin{array}{l}+.728 \\
+.366 \\
-.367 \\
-.772\end{array}$ & $\begin{array}{l}-.00078 \\
-.00044 \\
+.00040 \\
+.00092\end{array}$ & $\begin{array}{l}-.00215 \\
-.00110 \\
+.00114 \\
+.00231\end{array}$ \\
\hline
\end{tabular}

TABLE 18. Changes that would be introduced by a uniform displacement of the zero of the photometric scale by \pm 1.0 and \pm 0.5 percent independent of wavelength

\begin{tabular}{|c|c|c|c|c|c|c|c|c|c|c|c|c|c|c|c|}
\hline \multirow{2}{*}{ Filter } & \multicolumn{5}{|c|}{ Source $A$} & \multicolumn{5}{|c|}{ Source $B$} & \multicolumn{5}{|c|}{ Source $C$} \\
\hline & $\Delta X$ & $\Delta Y$ & $\Delta Z$ & $\Delta x$ & $\Delta y$ & $\Delta X$ & $\Delta Y$ & $\Delta Z$ & $\Delta x$ & $\Delta y$ & $\Delta X$ & $\Delta Y$ & $\Delta Z$ & $\Delta x$ & $\Delta y$ \\
\hline $\begin{array}{r}2101 \\
+1.0 \% \\
+.5 \% \\
-.5 \% \\
-1.0 \%\end{array}$ & $\begin{array}{r}-0.234 \\
-.118 \\
+.207 \\
+.411\end{array}$ & $\begin{array}{r}-0.202 \\
-.103 \\
+.315 \\
+.627\end{array}$ & $\begin{array}{r}0.000 \\
.000 \\
+.177 \\
+.352\end{array}$ & $\begin{array}{r}+0.00048 \\
+.00025 \\
-.00235 \\
-.00464\end{array}$ & $\begin{array}{r}-0.00048 \\
-.00025 \\
+.00068 \\
+.00133\end{array}$ & $\begin{array}{r}-0.202 \\
-.102 \\
+.241 \\
+.479\end{array}$ & $\begin{array}{r}-0.184 \\
-.095 \\
+.357 \\
+.711\end{array}$ & $\begin{array}{r}0.000 \\
.000 \\
+.424 \\
+.844\end{array}$ & $\begin{array}{r}+0.00059 \\
+.00031 \\
-.00522 \\
-.01025\end{array}$ & $\begin{array}{r}-0.00059 \\
-.00031 \\
-.00009 \\
-.00017\end{array}$ & $\begin{array}{r}-0.189 \\
-.096 \\
+.265 \\
+.527\end{array}$ & $\begin{array}{r}-0.176 \\
-.090 \\
+.372 \\
+.741\end{array}$ & $\begin{array}{r}0.000 \\
.000 \\
+.588 \\
+1.169\end{array}$ & $\begin{array}{r}+0.00064 \\
+.00033 \\
-.00729 \\
-.01427\end{array}$ & $\begin{array}{r}-0.00063 \\
-.00033 \\
-.00095 \\
-.00186\end{array}$ \\
\hline $\begin{array}{r}2102 \\
+1.0 \% \\
+.5 \% \\
-.5 \% \\
-1.0 \%\end{array}$ & $\begin{array}{r}-.400 \\
-.199 \\
+.197 \\
+.392\end{array}$ & $\begin{array}{r}-.452 \\
-.225 \\
+.223 \\
+.444\end{array}$ & $\begin{array}{r}-.335 \\
-.166 \\
+.166 \\
+.330\end{array}$ & $\begin{array}{r}+.00200 \\
+.00099 \\
-.00097 \\
-.00192\end{array}$ & $\begin{array}{r}+.00049 \\
+.00024 \\
-.00023 \\
-.00046\end{array}$ & $\begin{array}{r}-.434 \\
-.216 \\
+.213 \\
+.425\end{array}$ & $\begin{array}{r}-.499 \\
-.248 \\
+.246 \\
+.489\end{array}$ & $\begin{array}{r}-.816 \\
-.406 \\
+.402 \\
+.801\end{array}$ & $\begin{array}{r}+.00411 \\
+.00203 \\
-.00198 \\
-.00391\end{array}$ & $\begin{array}{r}+.00272 \\
+.00134 \\
-.00131 \\
-.00258\end{array}$ & $\begin{array}{l}-.472 \\
-.235 \\
+.232 \\
+.462\end{array}$ & $\begin{array}{r}-.518 \\
-.258 \\
+.255 \\
+.507\end{array}$ & $\begin{array}{r}-1.136 \\
-.565 \\
+.559 \\
+1.114\end{array}$ & $\begin{array}{r}+.00541 \\
+.00267 \\
-.00258 \\
-.00510\end{array}$ & $\begin{array}{r}+.00448 \\
+.00221 \\
-.00214 \\
-.00421\end{array}$ \\
\hline $\begin{array}{r}2103 \\
+1.0 \% \\
+.5 \% \\
-.5 \% \\
-1.0 \%\end{array}$ & $\begin{array}{r}-.524 \\
-.314 \\
+.530 \\
+1.056\end{array}$ & $\begin{array}{r}-.682 \\
-.367 \\
+.453 \\
+.901\end{array}$ & $\begin{array}{r}-.191 \\
-.108 \\
+.170 \\
+.339\end{array}$ & $\begin{array}{r}-.01614 \\
-.01004 \\
+.01768 \\
+.03265\end{array}$ & $\begin{array}{l}+.02066 \\
+.01251 \\
-.02164 \\
-.03996\end{array}$ & $\begin{array}{r}-.513 \\
-.299 \\
+.476 \\
+.946\end{array}$ & $\begin{array}{r}-.729 \\
-.385 \\
+.444 \\
+.884\end{array}$ & $\begin{array}{r}-.400 \\
-.233 \\
+.413 \\
+.821\end{array}$ & $\begin{array}{r}-.01128 \\
-.00685 \\
+.01095 \\
+.02029\end{array}$ & $\begin{array}{r}+.02325 \\
+.01381 \\
-.02405 \\
-.04455\end{array}$ & $\begin{array}{r}-.511 \\
-.297 \\
+.470 \\
+.936\end{array}$ & $\begin{array}{r}-.743 \\
-.390 \\
+.441 \\
+.878\end{array}$ & $\begin{array}{r}-.521 \\
-.306 \\
+.575 \\
+1.143\end{array}$ & $\begin{array}{r}-.00970 \\
-.00584 \\
+.00893 \\
+.01650\end{array}$ & $\begin{array}{r}+.02556 \\
+.01518 \\
-.02720 \\
-.05023\end{array}$ \\
\hline $\begin{array}{r}2104 \\
+1.0 \% \\
+.5 \% \\
-.5 \% \\
-1.0 \%\end{array}$ & $\begin{array}{r}-.984 \\
-.518 \\
+.513 \\
+1.021\end{array}$ & $\begin{array}{r}-.919 \\
-.473 \\
+.468 \\
+.932\end{array}$ & $\begin{array}{r}-.123 \\
-.061 \\
+.060 \\
+.120\end{array}$ & $\begin{array}{r}-.01780 \\
-.00918 \\
+.00857 \\
+.01659\end{array}$ & $\begin{array}{r}-.01742 \\
-.00868 \\
+.00810 \\
+.01569\end{array}$ & $\begin{array}{r}-.828 \\
-.433 \\
+.429 \\
+.854\end{array}$ & $\begin{array}{r}-.905 \\
-.463 \\
+.458 \\
+.911\end{array}$ & $\begin{array}{r}-.259 \\
-.129 \\
+.128 \\
+.255\end{array}$ & $\begin{array}{r}-.00650 \\
-.00340 \\
+.00328 \\
+.00645\end{array}$ & $\begin{array}{r}-.00903 \\
-.00455 \\
+.00439 \\
+.00863\end{array}$ & $\begin{array}{l}-.778 \\
-.406 \\
+.402 \\
+.800\end{array}$ & $\begin{array}{r}-.895 \\
-.457 \\
+.453 \\
+.901\end{array}$ & $\begin{array}{l}-.344 \\
-.171 \\
+.169 \\
+.336\end{array}$ & $\begin{array}{r}-.00428 \\
-.00224 \\
+.00217 \\
+.00429\end{array}$ & $\begin{array}{r}-.00673 \\
-.00340 \\
+.00331 \\
+.00652\end{array}$ \\
\hline $\begin{array}{r}2105 \\
+1.0 \% \\
+.5 \% \\
-.5 \% \\
-1.0 \%\end{array}$ & $\begin{array}{l}-.557 \\
-.277 \\
+.275 \\
+.547\end{array}$ & $\begin{array}{r}-.467 \\
-.232 \\
+.231 \\
+.459\end{array}$ & $\begin{array}{r}-.127 \\
-.063 \\
+.063 \\
+.125\end{array}$ & $\begin{array}{r}-.00059 \\
-.00029 \\
+.00029 \\
+.00058\end{array}$ & $\begin{array}{l}+.00002 \\
+.00001 \\
-.00002 \\
-.00003\end{array}$ & $\begin{array}{r}-.484 \\
-.241 \\
+.238 \\
+.474\end{array}$ & $\begin{array}{r}-.451 \\
-.225 \\
+.222 \\
+.442\end{array}$ & $\begin{array}{r}-.311 \\
-.154 \\
+.154 \\
+.305\end{array}$ & $\begin{array}{r}-.00055 \\
-.00028 \\
+.00026 \\
+.00053\end{array}$ & $\begin{array}{r}-.00015 \\
-.00008 \\
+.00007 \\
+.00013\end{array}$ & $\begin{array}{r}-.469 \\
-.234 \\
+.231 \\
+.459\end{array}$ & $\begin{array}{r}-.445 \\
-.222 \\
+.219 \\
+.436\end{array}$ & $\begin{array}{r}-.435 \\
-.217 \\
+.214 \\
+.426\end{array}$ & $\begin{array}{r}-.00048 \\
-.00024 \\
+.00024 \\
+.00047\end{array}$ & $\begin{array}{r}-.00017 \\
-.00008 \\
+.00009 \\
+.00017\end{array}$ \\
\hline
\end{tabular}

values of computed spectral-transmittance readings were counted as equal to zero on the assumption that no spectrophotometer-integrator system will be designed actually to subtract substantial amounts from the tristimulus sums to correspond to such negative values. Note that standard filters 2102 (yellow) and 2104 (blue) both are sensitive to this type of maladjustment. This corresponds to the fact that for both filters the spectral transmittance approaches but does not become less than 1 percent. Note also that filters 2101 (orange red) and 2103 (green) though sensitive to negative displacements of the instrument zero are less so for positive displacements. Filter 2101 , in particular, shows almost no change in chromaticity coordinates, $x, y$, for positive displacements. Positive displacements only serve to move the apparent cutoff of the curve of spectral transmittance slightly toward longer wavelength, but negative displacements cause the system to respond as if the filter transmitted 0.5 or 1 percent throughout the whole short-wave and middle-wave part of the visible spectrum (380 to $580 \mathrm{~m} \mu$ ) where the iransmittance is actually almost precisely zero. The errors introduced by negative displacements are in fact equiva- 
TABLE 19. Changes that would be introduced by a uniform displacement of the $100 \%$ of the photometric scale by \pm 1.0 and \pm 0.5 percent independent of wavelength

\begin{tabular}{|c|c|c|c|c|c|c|c|c|c|c|c|c|c|c|c|}
\hline \multirow{2}{*}{ Filter } & \multicolumn{5}{|c|}{ Source $A$} & \multicolumn{5}{|c|}{ Source $B$} & \multicolumn{5}{|c|}{ Source $C$} \\
\hline & $\Delta X$ & $\Delta Y$ & $\Delta Z$ & $\Delta x$ & $\Delta y$ & $\Delta X$ & $\Delta Y$ & $\Delta Z$ & $\Delta x$ & $\Delta y$ & $\Delta X$ & $\Delta Y$ & $\Delta Z$ & $\Delta x$ & $\Delta y$ \\
\hline $\begin{array}{r}2101 \\
+1.0 \% \\
+.5 \% \\
-.5 \% \\
-1.0 \%\end{array}$ & $\begin{array}{r}-0.676 \\
-.340 \\
+.344 \\
+.691\end{array}$ & $\begin{array}{r}-0.363 \\
-.182 \\
+.185 \\
+.371\end{array}$ & $\begin{array}{r}0.000 \\
.000 \\
.000 \\
.000\end{array}$ & $\begin{array}{r}0.00000 \\
.00000 \\
.00000 \\
.00000\end{array}$ & $\begin{array}{r}0.00000 \\
.00000 \\
.00000 \\
.00000\end{array}$ & $\begin{array}{r}-0.502 \\
-.252 \\
+.255 \\
+.513\end{array}$ & $\begin{array}{r}-0.279 \\
-.140 \\
+.141 \\
+.284\end{array}$ & $\begin{array}{r}0.000 \\
.000 \\
.000 \\
+.001\end{array}$ & $\begin{array}{r}0.00000 \\
.00000 \\
.00000 \\
.00000\end{array}$ & $\begin{array}{r}0.00000 \\
.00000 \\
.00000 \\
.00000\end{array}$ & $\begin{array}{r}-0.444 \\
-.223 \\
+.225 \\
+.452\end{array}$ & $\begin{array}{r}-0.249 \\
-.125 \\
+.126 \\
+.254\end{array}$ & $\begin{array}{r}0.000 \\
.000 \\
.000 \\
.000\end{array}$ & $\begin{array}{r}0.00000 \\
.00000 \\
.00000 \\
.00000\end{array}$ & $\begin{array}{r}0.00000 \\
.00000 \\
.00000 \\
.00000\end{array}$ \\
\hline $\begin{array}{r}2102 \\
+1.0 \% \\
+.5 \% \\
-.5 \% \\
-1.0 \%\end{array}$ & $\begin{array}{l}-.696 \\
-.350 \\
+.352 \\
+.709\end{array}$ & $\begin{array}{r}-.547 \\
-.275 \\
+.278 \\
+.558\end{array}$ & $\begin{array}{l}-.022 \\
-.011 \\
+.012 \\
+.024\end{array}$ & $\begin{array}{l}.00000 \\
.00000 \\
.00000 \\
.00000\end{array}$ & $\begin{array}{l}.00000 \\
.00000 \\
.00000 \\
.00000\end{array}$ & $\begin{array}{l}-.556 \\
-.280 \\
+.282 \\
+.567\end{array}$ & $\begin{array}{l}-.501 \\
-.252 \\
+.255 \\
+.512\end{array}$ & $\begin{array}{l}-.043 \\
-.022 \\
+.022 \\
+.045\end{array}$ & $\begin{array}{l}.00000 \\
.00000 \\
.00000 \\
.00000\end{array}$ & $\begin{array}{l}.00000 \\
.00000 \\
.00000 \\
.00000\end{array}$ & $\begin{array}{l}-.508 \\
-.255 \\
+.258 \\
+.518\end{array}$ & $\begin{array}{r}-.483 \\
-.243 \\
+.245 \\
+.492\end{array}$ & $\begin{array}{r}-.055 \\
-.028 \\
+.028 \\
+.056\end{array}$ & $\begin{array}{l}.00000 \\
.00000 \\
.00000 \\
.00000\end{array}$ & $\begin{array}{l}.00000 \\
.00000 \\
.00000 \\
.00000\end{array}$ \\
\hline $\begin{array}{r}2103 \\
+1.0 \% \\
+.5 \% \\
-.5 \% \\
-1.0 \%\end{array}$ & $\begin{array}{r}-.032 \\
-.016 \\
+.016 \\
+.032\end{array}$ & $\begin{array}{r}-.089 \\
-.045 \\
+.046 \\
+.092\end{array}$ & $\begin{array}{r}-.013 \\
-.006 \\
+.007 \\
+.013\end{array}$ & $\begin{array}{l}.00000 \\
.00000 \\
.00000 \\
.00000\end{array}$ & $\begin{array}{l}.00000 \\
.00000 \\
.00000 \\
.00000\end{array}$ & $\begin{array}{r}-.034 \\
-.017 \\
+.0018 \\
+.035\end{array}$ & $\begin{array}{r}-.107 \\
-.054 \\
+.054 \\
+.109\end{array}$ & $\begin{array}{r}-.023 \\
-.011 \\
+.011 \\
+.022\end{array}$ & $\begin{array}{l}.00000 \\
.00000 \\
.00000 \\
.00000\end{array}$ & $\begin{array}{l}.00000 \\
.00000 \\
.00000 \\
.00000\end{array}$ & $\begin{array}{r}-.035 \\
-.017 \\
+.018 \\
+.036\end{array}$ & $\begin{array}{r}-.112 \\
-.056 \\
+.056 \\
+.114\end{array}$ & $\begin{array}{r}-.026 \\
-.013 \\
+.014 \\
+.028\end{array}$ & $\begin{array}{l}.00000 \\
.00000 \\
.00000 \\
.00000\end{array}$ & $\begin{array}{l}.00000 \\
.00000 \\
.00000 \\
.00000\end{array}$ \\
\hline $\begin{array}{r}2104 \\
+1.0 \% \\
+.5 \% \\
-.5 \% \\
-1.0 \%\end{array}$ & $\begin{array}{r}-.067 \\
-.033 \\
+.034 \\
+.069\end{array}$ & $\begin{array}{l}-.058 \\
-.029 \\
+.029 \\
+.059\end{array}$ & $\begin{array}{l}-.232 \\
-. .117 \\
+.117 \\
+.236\end{array}$ & $\begin{array}{l}.00000 \\
.00000 \\
.00000 \\
.00000\end{array}$ & $\begin{array}{l}.00000 \\
.00000 \\
.00000 \\
.00000\end{array}$ & $\begin{array}{l}-.127 \\
-.064 \\
+.065 \\
+.130\end{array}$ & $\begin{array}{l}-.079 \\
-.040 \\
+.040 \\
+.080\end{array}$ & $\begin{array}{l}-.589 \\
-.296 \\
+.300 \\
+.602\end{array}$ & $\begin{array}{l}.00000 \\
.00000 \\
.00000 \\
.00000\end{array}$ & $\begin{array}{l}.00000 \\
.00000 \\
.00000 \\
.00000\end{array}$ & $\begin{array}{l}-.171 \\
-.086 \\
+.086 \\
+.174\end{array}$ & $\begin{array}{l}-.090 \\
-.045 \\
+.046 \\
+.092\end{array}$ & $\begin{array}{r}-.833 \\
-.419 \\
+.422 \\
+.849\end{array}$ & $\begin{array}{l}.00000 \\
.00000 \\
.00000 \\
.00000\end{array}$ & $\begin{array}{l}.00000 \\
.00000 \\
.00000 \\
.00000\end{array}$ \\
\hline $\begin{array}{r}2105 \\
+1.0 \% \\
+.5 \% \\
-.5 \% \\
-1.0 \%\end{array}$ & $\begin{array}{r}-.541 \\
-.272 \\
+.275 \\
+.552\end{array}$ & $\begin{array}{r}-.531 \\
-.267 \\
+.270 \\
+.543\end{array}$ & $\begin{array}{r}-.227 \\
-.114 \\
+.116 \\
+.232\end{array}$ & $\begin{array}{l}.00000 \\
.00000 \\
.00000 \\
.00000\end{array}$ & $\begin{array}{l}.00000 \\
.00000 \\
.00000 \\
.00000\end{array}$ & $\begin{array}{r}-.506 \\
-.254 \\
+.257 \\
+.517\end{array}$ & $\begin{array}{r}-.548 \\
-.275 \\
+.278 \\
+.559\end{array}$ & $\begin{array}{r}-.539 \\
-.270 \\
+.274 \\
+.550\end{array}$ & $\begin{array}{l}.00000 \\
.00000 \\
.00000 \\
.00000\end{array}$ & $\begin{array}{l}.00000 \\
.00000 \\
.00000 \\
.00000\end{array}$ & $\begin{array}{r}-.511 \\
-.257 \\
+.259 \\
+.521\end{array}$ & $\begin{array}{r}-.554 \\
-.279 \\
+. .81 \\
+.565\end{array}$ & $\begin{array}{r}-.743 \\
-.374 \\
+.377 \\
+.785\end{array}$ & $\begin{array}{l}.00000 \\
.00000 \\
.00000 \\
.00000\end{array}$ & $\begin{array}{l}.00000 \\
.00000 \\
.00000 \\
.00000\end{array}$ \\
\hline
\end{tabular}

lent to admixture of the corresponding amounts of the source color, and positive displacements are equivalent to subtraction of corresponding amounts of the source color, unless (as in filters 2101 and 2103) there are substantial spectral regions within which the filters have zero transmittance. Except for this difference between positive and negative displacements caused by counting negative values of transmittance arbitrarily as zero, the changes are substantially linear with displacement of the zero.

\section{c. 100 Percent Point of Photometric Scale}

Table 19 shows the changes corresponding to a displacement of the 100 percent point of the photometric scale by \pm 0.5 and \pm 1.0 percent independent of wavelength. As is obvious, such displacements have no influence on chromaticity coordinates whatsoever. The changes produced in the tristimulus values, except for rejection errors, are precisely linear with the displacement. Standard filter 2105 (selective neutral), since it has the highest average transmittance, is the most sensitive of the five to this maladjustment.

\section{d. Stray-Energy Errors}

The basic idea of a spectrophotometer is to irradiate the specimen with flux confined to a narrow spectral band and to compare the flux leaving the specimen to that incident on it. No spectrophotometer succeeds perfectly in confining the flux incident on the specimen to the narrow spectral band intended; the specimen is always irradiated by energy outside this band, called stray energy (cosmic rays, radiant flux from the room leaking into the instrument, radiant flux from the instrument source reaching the specimen by multiple reflection within the instrument without passing through the dispersing elements, radiant flux reaching the specimen passing through the dispersing elements after having been scattered by irregularities of the optical surfaces, or after having been scattered by dust particles on them, and so on).

Spectrophotometers, like the GE or Cary-14, having two dispersing systems are likely to show negligible stray-energy errors; those, like the Beckman DU or König-Martens, having but a single prism or grating are likely to show important strayenergy errors, particularly if the integrating attachment prevents the employment of stray-energy filters. For such instruments it is particularly important to have a means of checking for the amount of stray-energy errors, because the accidental displacement of a baffle within the instrument, or accumulation of dust on the optical surfaces, may introduce large errors following continued use of a system initially free of significant strayenergy error.

The most frequent kind of stray-energy error arises from the incidence of radiant flux having the spectral distribution of the instrument source. So as to assist purchasers of a set of standard filters to use them for the detection of stray-energy errors of this most frequent sort, calculations have been made on the assumption that the stray energy and the dispersed energy alike have the spectral distribution of CIE source $A$ (color temperature $2,854^{\circ} \mathrm{K}$ ), and that the specimen receives a constant small stray irradiance of this sort regardless of nominal wavelength.

If $H_{\lambda}$ is the irradiance of the detector from dispersed flux from source $A$, and if the spectral sensitivity of the detector is $S_{\lambda}$, then, in the absence of stray energy the response of the detector for the blank beam will be $k H_{\lambda} S_{\lambda} \Delta \lambda$, where $\Delta \lambda$ is the spec- 
tral band width, and $k$ is the constant of proportionality. Similarly, the response of the detector with a specimen of spectral transmittance, $T_{\lambda}$, inserted into the beam will be $k H_{\lambda} S_{\lambda} T_{\lambda} \Delta \lambda$. The reading, $R_{\lambda}$, of the spectrophotometer will be the ratio: $k H_{\lambda} S_{\lambda} T_{\lambda} \Delta \lambda / k H_{\lambda} S_{\lambda} \Delta \lambda$, and this ratio is seen to be equal to $T_{\lambda}$; so $R_{\lambda}=T_{\lambda}$, as intended.

If now there is stray energy of spectral irradiance, $f H_{\lambda}$, where $f$ is a small fraction chosen arbitrarily to be within the range of usual stray energy, then the reading, $R_{s \lambda}$, of the spectrophotometer may be expressed as:

$$
R_{s \lambda}=\frac{H_{\lambda} S_{\lambda} T_{\lambda} \Delta \lambda+f \Sigma H_{\lambda} S_{\lambda} T_{\lambda} \Delta \lambda}{H_{\lambda} S_{\lambda} \Delta \lambda+f \Sigma H_{\lambda} S_{\lambda} \Delta \lambda}
$$

The summations correspond to the fact that the stray energy is undispersed, and must be evaluated over the entire range for which the product, $H_{\lambda} S_{\lambda}$, is significantly different from zero. It will be noticed from eq 5 that if the fraction, $f$, of the stray energy is sufficiently small, then the spectrophotometer will read spectral transmittance correctly $\left(R_{s \lambda}=T_{\lambda}\right)$; but for all spectral regions in which $H_{\lambda} S_{\lambda} \Delta \lambda$ is small compared to $f \Sigma H_{\lambda} S_{\lambda} \Delta \lambda$, the reading, $R_{s \lambda}$, will approach the transmittance of the filter for the aspect

TABLE 20. Spectral sensituvities for two types of detector: photomultiplier type and lead sulfide type

\begin{tabular}{|c|c|c|c|}
\hline $\begin{array}{l}\text { Wave- } \\
\text { length }\end{array}$ & $\begin{array}{c}\text { Photo- } \\
\text { multiplier } \\
\text { sensitivity }\end{array}$ & $\begin{array}{l}\text { Wave- } \\
\text { length }\end{array}$ & $\begin{array}{l}\text { Lead sul- } \\
\text { fide sensi- } \\
\text { tivity }\end{array}$ \\
\hline$m \mu$ & & $\mu$ & \\
\hline 300 & 340 & 0.3 & 39.5 \\
\hline 310 & 450 & .4 & 51.0 \\
\hline 320 & 545 & & \\
\hline 330 & 630 & .5 & 62.5 \\
\hline 340 & 655 & .6 & $\begin{array}{l}74.0 \\
85.0\end{array}$ \\
\hline 350 & 665 & .8 & 96.0 \\
\hline 360 & 665 & .9 & 107.5 \\
\hline 370 & 660 & & \\
\hline 380 & 655 & 1.0 & 122 \\
\hline 390 & 642 & 1. 1 & $\begin{array}{l}122 \\
124\end{array}$ \\
\hline 400 & 620 & 1. 3 & $\begin{array}{l}124 \\
124\end{array}$ \\
\hline 410 & 595 & 1. 4 & 146 \\
\hline 420 & 575 & & \\
\hline 430 & 555 & 1.5 & 152 \\
\hline 440 & 525 & 1. 6 & 154 \\
\hline & & 1.7 & 164 \\
\hline 450 & 500 & 1.8 & 177 \\
\hline 460 & 475 & 1.9 & 188 \\
\hline 470 & 440 & & \\
\hline 480 & 410 & 2. 0 & 195 \\
\hline 490 & 375 & 2.1 & 197 \\
\hline & & 2. 2 & 204 \\
\hline 500 & 348 & 2.3 & 198 \\
\hline 510 & 318 & 2.4 & 186 \\
\hline 520 & 285 & & \\
\hline 530 & 255 & 2.5 & 171 \\
\hline 540 & 220 & 2. 6 & 154 \\
\hline & & 2.7 & 107 \\
\hline 550 & 187 & 2.8 & 48 \\
\hline 560 & 151 & 2.9 & 26 \\
\hline 570 & 122 & & \\
\hline 580 & 96 & 3. 0 & 13 \\
\hline 590 & 72.5 & 3.1 & 6 \\
\hline 600 & 51.0 & $\begin{array}{l}3.2 \\
3.3\end{array}$ & $\begin{array}{l}2 \\
0\end{array}$ \\
\hline 610 & 35.0 & & \\
\hline 620 & 20.0 & & \\
\hline 630 & 9.5 & & \\
\hline 640 & 4. 0 & & \\
\hline 650 & 1. 6 & & \\
\hline 660 & 0.8 & & \\
\hline 670 & 0.4 & & \\
\hline 680 & 0.2 & & \\
\hline 690 & 0.1 & & \\
\hline
\end{tabular}

TABLE 21. Values of transmittance $\mathrm{T}_{\mathrm{ad}}$ of the five filters of master set No. 3 for the aspect of source-A energy detected by photomultiplier and lead sulfide detectors

\begin{tabular}{|c|c|c|c|c|c|}
\hline Filter & 2101 & 2102 & 2103 & 2104 & 2105 \\
\hline Photomultiplier & 0.076 & 0.233 & 0. 086 & 0.410 & 0.543 \\
\hline Lead sulfide_.................. & 0.868 & 0.664 & 0.200 & 0.605 & 0.845 \\
\hline
\end{tabular}

of source $A$ responded to by the detector, $T_{a d}$, or $R_{s \lambda} \rightarrow T_{a d}$.

The summations have been computed for the five standard filters over the spectral range 0.3 to $3.3 \mu$ for two spectral-sensitivity functions given in table 20 , one intended to be representative of detectors of the photomultiplier type; the other, of the lead sulfide type. Table 21 gives the values of $T_{a d}$ for the five filters evaluated by these two types of detectors, and figures 2 to 6 show the adopted values of spectral transmittance for the filters of master set No. 3 compared to values of $R_{s \lambda}$ for $f=0.01$. It will be noted that the curves of $R_{s \lambda}$ approach the value of $T_{a d}$ in the spectral regions where the detector response is relatively low.

Table 22 shows the changes in tristimulus values, $X, Y, Z$, and chromaticity coordinates, $x, y$, caused by the introduction of the amounts of stray energy corresponding to $f=0.001,0.005$, and 0.010 . It will

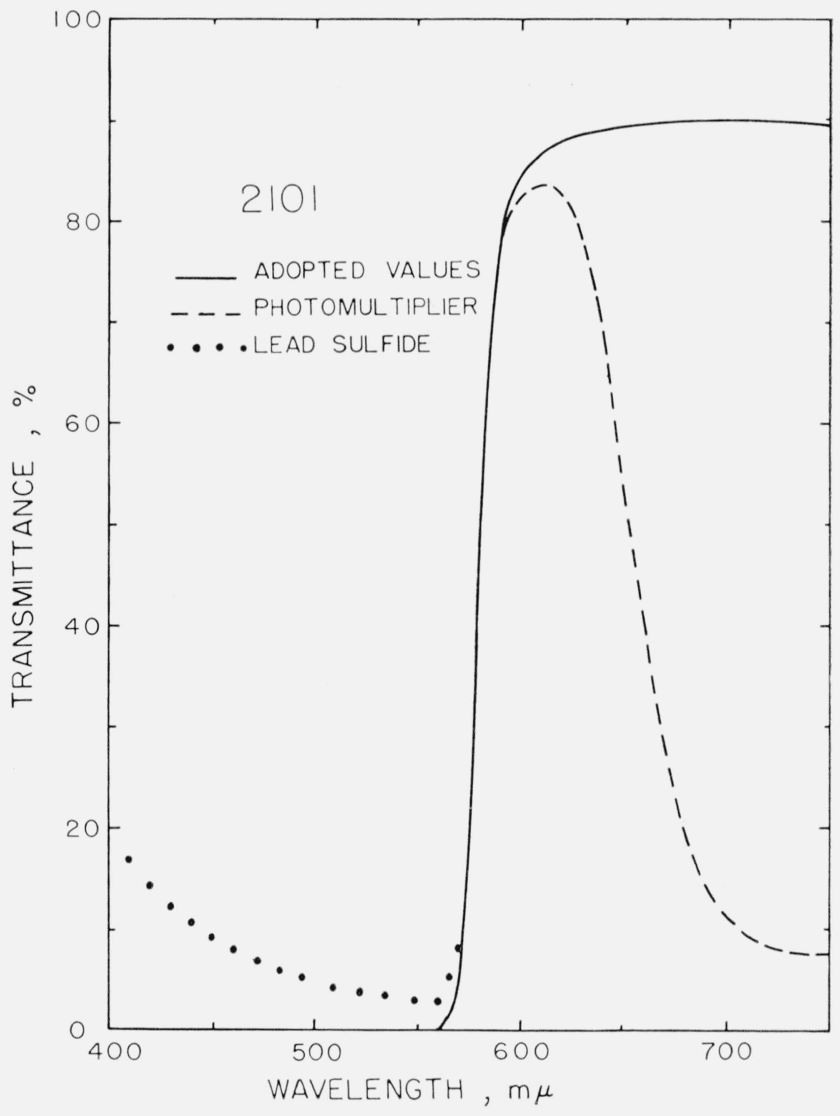

Figure 2. Adopted values of spectral transmittance for master set No. 3, 2101 orange-red glass compared to values of $\mathbf{R}_{s \lambda}$ for $\mathrm{f}=0.01$ for photomultiplier and lead sulfide systems. 


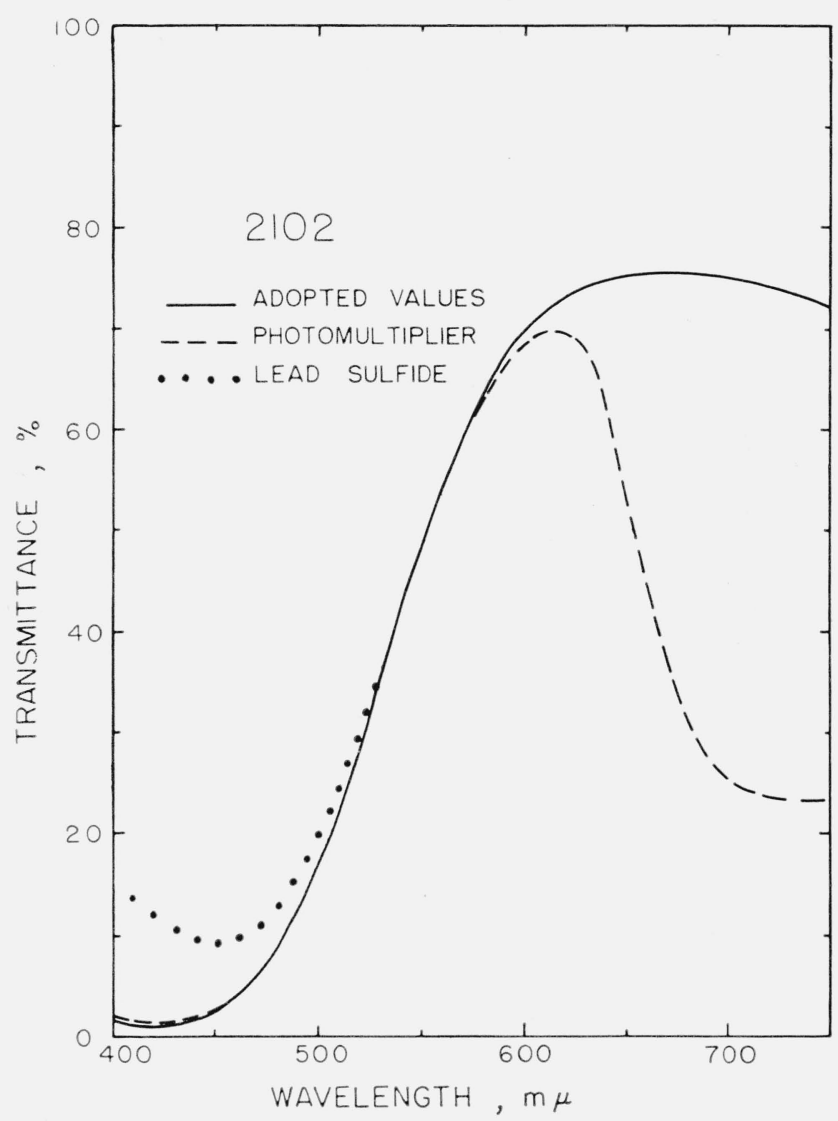

Figure 3. Adopted values of spectral transmittance for master set No. 3, 2102 yellow glass compared to values of $\mathrm{R}_{s \lambda}$ for $\mathrm{f}=0.01$ for photomultiplier and lead sulfide systems.

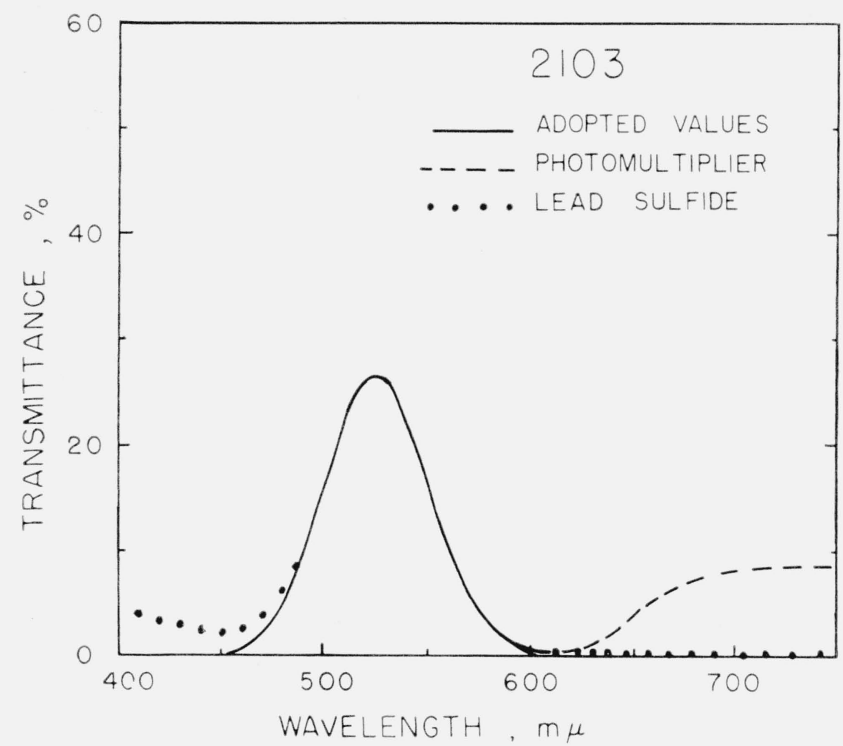

Figure 4. Adopted values of spectral transmittance for master set No. 3, 2103 sextant green glass compared to values of $\mathrm{R}_{s \lambda}$ for $\mathrm{f}=0.01$ for photomultiplier and lead sulfide systems.

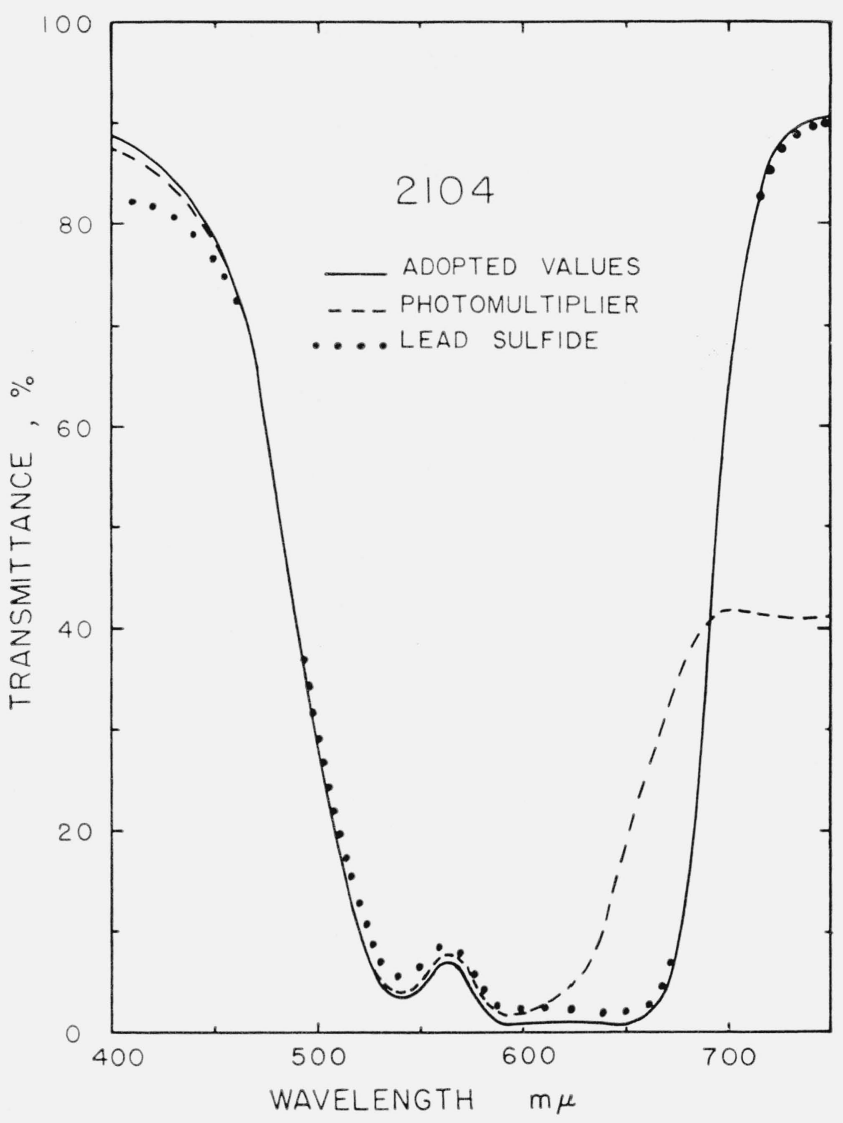

Figure 5. Adopted values of spectral transmittance for master set No. 3, 2104 cobalt blue glass compared to values of $\mathbf{R}_{s \lambda}$ for $\mathrm{f}=0.01$ for photomultiplier and lead sulfide systems.

be noted that standard filter 2101 (orange red) is sensitive to stray energy with a photomultipliertype detector by change in its $X$ tristimulus value and to stray energy with a lead sulfide detector by change in its $Z$ tristimulus value, as is also filter 2102 (yellow). Filter 2103 (green) also serves for both types of detector, the lead sulfide detector through the $x$ chromaticity coordinate, and the photomultiplier through the $y$ coordinate. Filter 2104 (blue) indicates by its $X$ tristimulus value the presence of stray energy with the photomultiplier type of detector. For the lead sulfide detector these changes are closely linear with fraction, $f$, of stray energy ; for the photomultiplier type of detector they vary approximately as $f^{2 / 3}$.

\section{e. Inertia Errors}

Table 23 shows the corresponding changes introduced by inertia errors computed from formula 2 . All standard filters are influenced appreciably by inertia errors; filters 2101 and 2102 , in $X$ and $\dot{Y}$; filter 2103 , in $x$; and filters 2104 and 2105 in $Z$. 


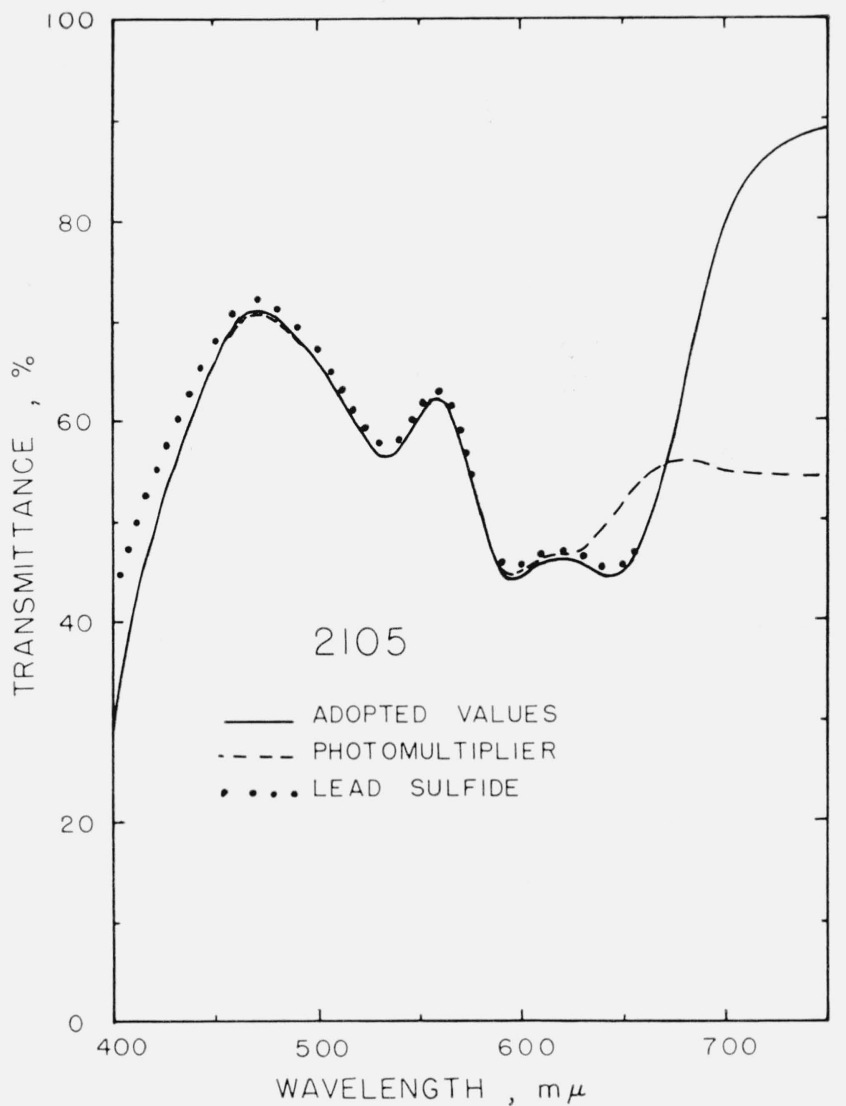

FIGURE 6. Adopted values of spectral transmittance of master set No. 3, 2105 selective neutral glass compared to values of $\mathrm{R}_{s \lambda}$ for $\mathrm{f}=0.01$ for photomultiplier and lead sulfide systems.

\subsection{Diagnosis of Maladjustments}

Table 24 identifies which of the certified variables $(X, Y, Z, x, y)$ of which standard filters serves best to detect one or another type of maladjustment or malfunction of the spectrophotometer-integrator system. It thus summarizes the uses of each filter and indicates the degree to which the choice of filter has been found justified. This table also suggests a possible simple systematic way to diagnose the simple ills of a spectrophotometer-integrator system from the differences between the actual instrument readings, $X_{r}, Y_{\tau}, Z_{\tau}, x_{r}, y_{\tau}$, and the corresponding par values $X_{0}, Y_{0}, Z_{0}, x_{0}, y_{0}$.

TABLE 22. Changes in tristimulus values, X, Y, Z, and chromaticity coordinates, $\mathrm{x}, \mathrm{y}$, caused by the introduction of the amounts of stray energy corresponding to $\mathrm{f}=0.010,0.005$, and 0.001

MPT (photomultiplier-type detector); PbS (lead sulfide type detector)

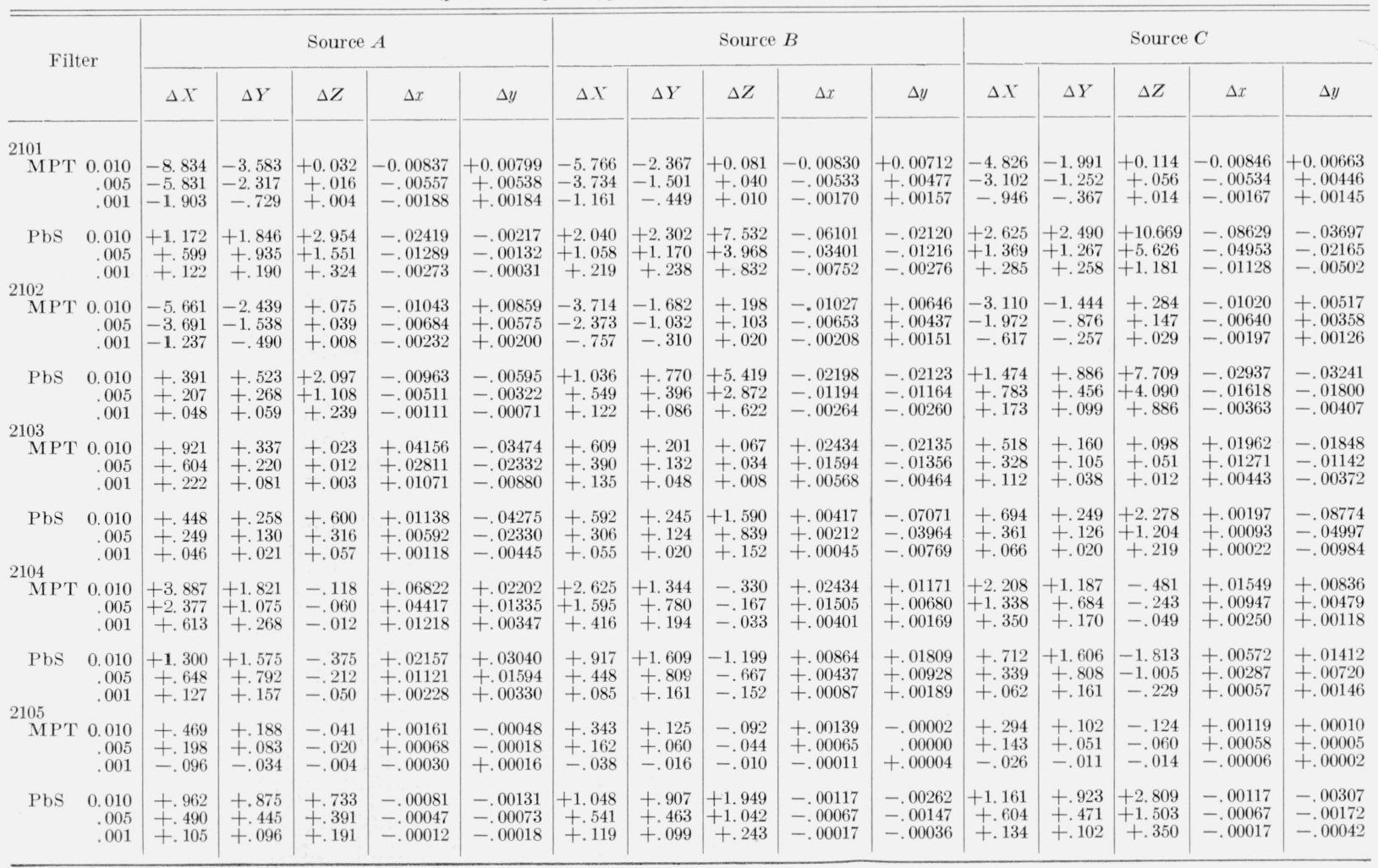


TABLE 23. Changes introduced by inertia errors computed from formula 2

\begin{tabular}{|c|c|c|c|c|c|}
\hline Filter & $\Delta X$ & $\Delta Y$ & $\Delta Z$ & $\Delta x$ & $\Delta y$ \\
\hline \multicolumn{6}{|c|}{ Source $A$} \\
\hline $\begin{array}{l}2101 \\
2102 \\
2103 \\
2104 \\
2105\end{array}$ & $\begin{array}{r}+0.647 \\
+.206 \\
-.107 \\
-.035 \\
-.062\end{array}$ & $\begin{array}{r}+0.546 \\
+.297 \\
-.120 \\
-.120 \\
-.097\end{array}$ & $\begin{array}{r}+0.001 \\
+.045 \\
+.035 \\
-.155 \\
+.070\end{array}$ & $\begin{array}{r}-0.00122 \\
-.00074 \\
-.00468 \\
+.00065 \\
-.00019\end{array}$ & $\begin{array}{r}+0.00122 \\
+.00046 \\
+.00065 \\
-.00196 \\
-.00046\end{array}$ \\
\hline \multicolumn{6}{|c|}{ Source $B$} \\
\hline $\begin{array}{l}2101 \\
2102 \\
2103 \\
2104 \\
2105\end{array}$ & $\begin{array}{r}+0.564 \\
+.196 \\
-.101 \\
-.068 \\
-.032\end{array}$ & $\begin{array}{r}+0.483 \\
+.320 \\
-.106 \\
-.167 \\
-.097\end{array}$ & $\begin{array}{r}+0.001 \\
+.090 \\
+.067 \\
-.332 \\
+.207\end{array}$ & $\begin{array}{r}-0.00138 \\
-.00099 \\
-.00440 \\
+.00028 \\
-.00036\end{array}$ & $\begin{array}{r}+0.00137 \\
+.00039 \\
-.00089 \\
-.00138 \\
-.00077\end{array}$ \\
\hline \multicolumn{6}{|c|}{ Source $C$} \\
\hline $\begin{array}{l}2101 \\
2102 \\
2103 \\
2104 \\
2105\end{array}$ & $\begin{array}{r}+0.528 \\
+.192 \\
-.097 \\
-.086 \\
-.010\end{array}$ & $\begin{array}{r}+0.455 \\
+.326 \\
-.098 \\
-.186 \\
-.095\end{array}$ & $\begin{array}{r}+0.001 \\
+.116 \\
+.084 \\
+.440 \\
+.305\end{array}$ & $\begin{array}{r}-0.00144 \\
-.00109 \\
-.00428 \\
+.00023 \\
-.00036\end{array}$ & $\begin{array}{r}+0.00143 \\
+.00031 \\
-.00154 \\
-.00116 \\
-.00085\end{array}$ \\
\hline
\end{tabular}

TABLE 24. Identification of the variable (X, Y, Z, x, y) and standard filter giving detection, at optimum or nearly optimum sensitivity, of various kinds of malfunction

\begin{tabular}{|c|c|c|c|c|c|c|}
\hline Malfunction $\quad$ Filter & 2101 & 2102 & 2103 & 2104 & 2105 & $\begin{array}{c}\text { See } \\
\text { table }\end{array}$ \\
\hline Wavele & $X Y x y$ & & $x$ & $Z y$ & & 17 \\
\hline Zero point of photometric scale & $x\left(^{*}\right)$ & $x(C)$ & $y$ & $x y(A)$ & & 18 \\
\hline $100 \%$ & $X Y$ & $X Y$ & & $Z$ & $X Y Z$ & 19 \\
\hline photomultiplier.. & $X$ & $X x$ & $x$ & $x$ & & 22 \\
\hline Stray-energy lead sulfide. & $Z x$ & $Z x$ & $y$ & $y$ & & 22 \\
\hline Inertia & $X Y$ & $X Y$ & $x$ & $Z$ & $Z$ & 23 \\
\hline
\end{tabular}

$\left(^{*}\right)$ Use this variable only if $x_{r}$ is less than $x_{0}$

(C) Use this variable only if the integrations are carried out for source $C$.

(A) Use this variable only if the integrations are carried out for source $A$.

If it were known that the malfunctions of the spectrophotometer-integrator system were confined to the five listed in table 24 , and if the precision of the system were substantially perfect, it would be possible to evaluate easily the extent of each of these types of malfunction from the differences between the actual instrument readings and the par values. Note that for each source used in integration the information regarding malfuction of the instrument obtained in this way has no less than 15 degrees of freedom (three tristimulus values for each of the five filters). If the uniform displacement of the wavelength scale were designated $\Delta_{\lambda}$, the displacement of the 100 percent point by $\Delta_{100}$, the strayenergy fraction, $f$, by $\Delta_{f}$, and the inertia constant by $\Delta_{i}$, then we may write an expression for, say, $\dot{X}_{r}-X_{0}$ for standard filter 2101 (orange red) that states merely that the difference between $X_{r}$ and $X_{0}$ is made up of contributions from the only types of malfunction that the system has, thus:

$X_{r}-X_{0}=\Delta_{\lambda} \frac{\partial X}{\partial \Delta_{\lambda}}+\Delta_{0} \frac{\partial X}{\partial \Delta_{0}}+\Delta_{100} \frac{\partial X}{\partial \Delta_{100}}+\Delta_{f} \frac{\partial X}{\partial \Delta_{f}}+\Delta_{i} \frac{\partial X}{\partial \Delta_{i}}$.
Note that 14 other such expressions can be written. The five variables are thus over-determined, and a least-square analysis should result in precise values of the five unknowns even with some lack of precision in the instrument reading. Note that the partial derivatives of eq 6 have been sufficiently well evaluated in tables 17, 18, 19, 22, and 23 . The values of $\Delta_{\lambda}, \Delta_{0}, \Delta_{100}, \Delta_{f}$, and $\Delta_{i}$ that might be found in this way are in the same units in which the partial derivatives, read from the tables, are expressed. Thus, if $\partial x / \partial \Delta_{\lambda}$ is read from table 17 as amount per millimicron, $\Delta_{\lambda}$ will be in $m \mu$, and if $\partial X / \partial \Delta_{i}$ is read from table 23 , which is based on $k=-0.07, \Delta_{i}$ evaluates $k$ of eq 2 in multiples of 0.07 .

Since actual spectrophotometer-integrator systems are beset with more complicated malfunctions than the five simple types listed in table 24 , and since the precision may be low enough so that not all of the differences like $X_{r}-X_{0}$ will be significant, it is presumed that this least-square solution for unknowns from 15 observation equations will usually not be worth doing. Table 24 suggests the following simplified procedure:

1. Determine the displacement of the 100 percent point on the photometric scale, $\Delta_{100}$, from the average of the 8 variables specified in table 19 as responsive to this type of malfunction:

$$
\begin{aligned}
\Delta_{100}=\frac{1}{8}\left[\Sigma^{1,2,5} \frac{\left(X_{r}-X_{0}\right)}{\partial X / \partial \Delta_{100}}+\Sigma^{1,2,5}\right. & \frac{\left(Y_{r}-Y_{0}\right)}{\partial Y / \partial \Delta_{100}} \\
& \left.+\Sigma^{4,5} \frac{\left(Z_{r}-Z_{0}\right)}{\partial Z / \partial \Delta_{100}}\right] .
\end{aligned}
$$

The partial derivatives are obtained from table 19 . The first two summations are to be taken for standard filters 2101,2102 , and 2105 ; the third summation, for standard filters 2104 and 2105 .

2. Tentatively (see next paragraph) determine wavelength-scale displacement $\Delta_{\lambda}$ as the solution of the following two simultaneous equations:

$$
\left.\begin{array}{l}
\text { For filter 2103, } x_{r}-x_{0}=\Delta_{\lambda}\left(\partial x / \partial \Delta_{\lambda}\right)+\Delta_{0}\left(\partial x / \partial \Delta_{0}\right) \\
\text { For filter 2101, } y_{r}-y_{0}=\Delta_{\lambda}\left(\partial y / \partial \Delta_{\lambda}\right)+\Delta_{0}\left(\partial y / \partial \Delta_{0}\right)
\end{array}\right\}
$$

where the partial derivatives are read from tables 17 and 18. Incidental to this solution for $\Delta_{\lambda}$ there will also be found a solution for $\Delta_{0}$, but this should be set aside.

The idea behind this recommendation for finding the wavelength-scale displacement is that the $x$-coordinate of filter 2103 and the $y$-coordinate of filter 2101 are the most sensitive indications of wavelength-scale displacement. Note also that by using chromaticity coordinates, no account need be taken even of very large displacements in the 100 percent point found from eq 6 , because such displacements have no influence on the chromaticity coordinates. This plan is strictly applicable to spectrophotometerintegrator systems having negligible stray-energy and inertia errors, and should apply very well to 
systems involving double dispersion. It is believed to be worth trying for other systems as well.

3. Determine the displacement of the zero-point from each of four equations, two of them in $x$ coordinate for standard filters 2101 and 2102, and two in $y$-coordinate for standard filters 2103 and 2104 .

For filters 2101 and 2102 :

$$
\left.\begin{array}{l}
\Delta_{0}=\left[\left(x_{r}-x_{0}\right)-\Delta_{\lambda}\left(\partial x / \partial \Delta_{\lambda}\right)\right] /\left(\partial x / \partial \Delta_{0}\right)
\end{array}\right\}
$$

For filters 2103 and 2104 :

$$
\left.\Delta_{0}=\left[\left(y_{r}-y_{0}\right)-\Delta_{\lambda}\left(\partial y / \partial \Delta_{\lambda}\right)\right] /\left(\partial y / \partial \Delta_{0}\right)\right]
$$

where the partial derivatives are found from tables 17 and 18 , the value of $\Delta_{\lambda}$ is that found from eq 8 . The average of the four values of zero-point displacement so found is close to the best available from the actual and par values for the five standard filters; the deviations of the individual values from this average is an indication of the extent to which other types of malfunction are afflicting the system.

4. Analogous procedures might be used for systems afflicted with stray energy (single-dispersion systems) in which the partial derivatives would be read from table 22 , and for systems afflicted with inertial effects in which the partial derivatives would be read from table 23 . It seems likely, however, to be more useful to evaluate stray energy by comparison of the actual curves of spectral transmittance obtained on the spectrophotometer of the system with the applicable curve of $R_{s \lambda}$ found from eq 5 ; see figures 2 through 6 .

\section{Summary}

A reexamination has been made of the fundamental measurement of spectral transmittance of nonscattering transparent colored media. A search made to resolve errors often considered as negligible or selfcompensating showed the significance of errors that may arise from lack of consideration of stray energy, slit width, back reflectance, and recorder inertia.

The effect of type of integration of the spectrophotometer data in the conversion to colorimetric terms showed that summations by the $10 \mathrm{~m} \mu$ weighted ordinate method or by the 30-selected-ordinate method are sufficient for most colorimetric work.

The effect of stray energy on both spectrophotometric and colorimetric data is illustrated.
We acknowledge the assistance of Victor R. Weidner in checking most of the tabulations of data in the tables of this report, Mrs. Iola Smith for the visual comparisons of the limit samples of these glasses on the Judd chromaticity-difference colorimeter as well as for the checking of the $Y$ scale of the red duplicates on the Walker-Haupt transmittance photometer, and Miss Marion Belknap for the spectrophotometric measurements on the Beckman DU and the König-Martens spectrophotometers.

\section{References}

[1] Hardy, A. C., A new recording spectrophotometer, J. Opt. Soc. Am. 25, 305 (1935).

[2] Michaelson, J. L., Construction of the General Electric recording spectrophotometer, J. Opt. Soc. Am. 28, 365 (1938).

[3] MeNicholas, H. J., Equipment for routine spectral transmission and reflection measurements, BS J. Research 1, 793 (1928) RP30.

[4] Gibson, K. S. and Keegan, H. J., Calibration and operation of the General Electric recording spectrophotometer of the NBS, J. Opt. Soc. Am. 28, 372 (1938).

[5] Gibson, K. S. and Balcom, M. M., Transmission measurements with the Beckman quartz spectrophotometer, J. Research NBS 38, 601 (1947) RP1798; also J. Opt. Soc. Am. 3\%, 593 (1947).

[6] Gibson, K. S., Spectrophotometry, NBS Circ. 484, Sept. $15,1949$.

[7] Forsythe, W. E. (ed), Measurement of Radiant Energy (McGraw-Hill Book Company, Inc., New York, N.Y. and London, 1937).

[8] Keegan, H. J., Spectrophotometric and colorimetric instrumentation and calibration. General Electric Color Measurement Course, The Wentworth-by-theSea, Portsmouth, N.H., Sept. 24-28, 1956.

[9] Middleton, W. E. Knowles, The measurement of strongly reflecting transmission samples with the commercial recording spectrophotometer, J. Opt. Soc. Am. 38, 74 (1948).

[10] Hardy, A. C., Handbook of Colorimetry, Cambridge, Mass., Technology Press (1936).

[11] Judd, D. B., Extension of the standard visibility function to intervals of 1 millimicron by third-difference osculatory interpolation, J. Res. NBS 6, 465 (1931), RP289; also J. Opt. Soc. Am. 21, 267 (1931).

[12] Dixon, W. J. and Massey, F. J., Introduction to Statistical Analysis, 2d ed., MeGraw-Hill, 1957.

[13] Judd, D. B., Specification of uniform color tolerances for textiles, Textile Research 9, 253 (1939). 